
FOR EASTERN AFRICA@,

Paying the Price: A Study on Criminalization of Land and Environmental Rights Defenders in East Africa 


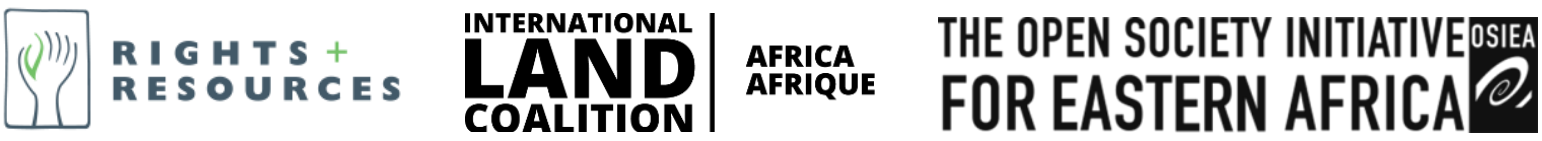

RIGHTS AND RESOURCES INITIATIVE | FEBRUARY 2021

\title{
Paying the Price: A Study on Criminalization of Land and Environmental Rights Defenders in East Africa
}

\author{
Technical Report
}

\footnotetext{
Prepared for the International Land Coalition, Rights and Resources Initiative, and Open Society Initiative for Eastern Africa by Ivan Okuda
} 


\section{About the Rights and Resources Initiative}

The Rights and Resources Initiative is a global Coalition of more than 150 organizations dedicated to advancing the forest, land, and resource rights of Indigenous Peoples, Afro-descendants, local communities, and the women within these groups. Members capitalize on each other's strengths, expertise, and geographic reach to achieve solutions more effectively and efficiently. RRI leverages the power of its global Coalition to amplify the voices of local peoples and proactively engage governments, multilateral institutions, and private sector actors to adopt institutional and market reforms that support the realization of rights. By advancing a strategic understanding of the global threats and opportunities resulting from insecure land and resource rights, RRI develops and promotes rights-based approaches to business and development and catalyzes effective solutions to scale rural tenure reform and enhance sustainable resource governance.

RRI is coordinated by the Rights and Resources Group, a non-profit organization based in Washington, DC. For more information, please visit www.rightsandresources.org.

\section{Partners}

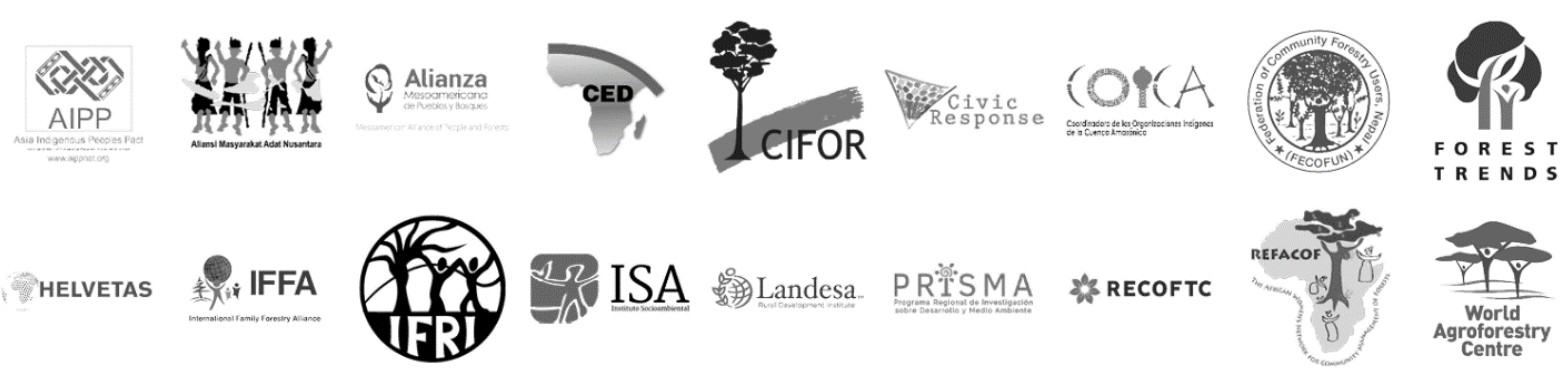

Sponsors

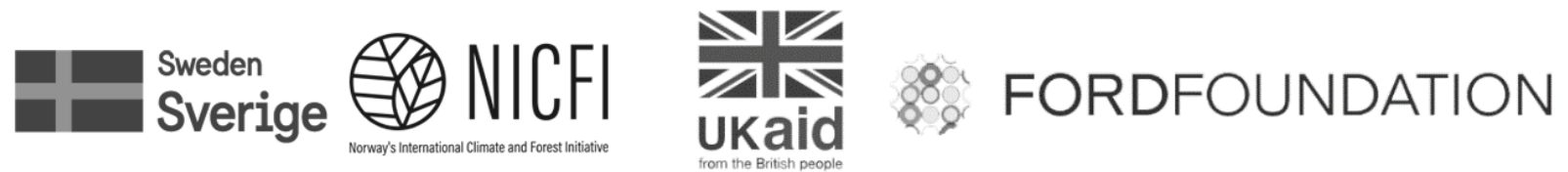

The views presented here are not necessarily shared by the agencies that have generously supported this work.

This work is licensed under a Creative Commons Attribution License CC BY 4.0. 


\section{About International Land Coalition Africa}

The International Land Coalition Africa (ILC Africa) is the regional platform of the International Land Coalition (ILC). With almost two-thirds of ILC's total membership, ILC Africa brings together 76 members across 26 countries in Sub-Saharan Africa. Recently, ILC Africa has recorded outcomes toward people-centred land governance, such as: the Participatory Rangelands Management in Kenya and Tanzania; local adoption and use of LANDex; the Kilimanjaro Charter of Demand; landrelated constitutional changes in South Africa; land redistribution in Tanzania; release of land defenders in DRC, Cameroon and Madagascar; customary law shift in favour of gender justice in South Africa and Zimbabwe; the translation of land codes into images in Togo-to name but a few. ILC Africa also engages regularly with international partners, such as the African Union (AU), Regional Economic Communities (RECS), and various United Nations agencies.

\section{About the Open Society Initiative for East Africa}

The Open Society Initiative for East Africa (OSIEA) supports and promotes public participation in democratic governance, the rule of law, and respect for human rights by awarding grants, developing programs, and bringing together diverse civil society leaders and groups. OSIEA seeks to promote open society and to consolidate democratic principles and practices through increased public participation and the creation of a strong institutionalized rights framework. OSIEA seeks to play an active role in encouraging open, informed dialogue about issues of national importance. 


\section{Table of Contents}

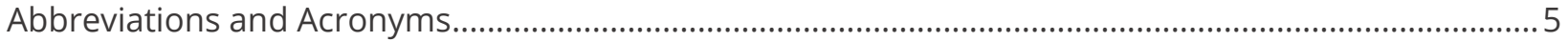

1.0 Context and Background to Criminalization of Land and Environmental Rights Defenders

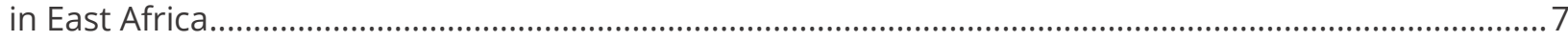

2.0 Country-Specific Cases of Criminalization of LERDs in East Africa.

3.0 General Observations on Steps Leading to Violence against or Criminalization of LERDs in East Africa.

4.0 Existing Strategies and Resources to Address the Criminalization of LERDs in East Africa, and Organizations Working on the Issue at the Local, National, and Regional Levels ..........................46

5.0 Main Findings (Conclusion) and Recommendations .......................................................................51

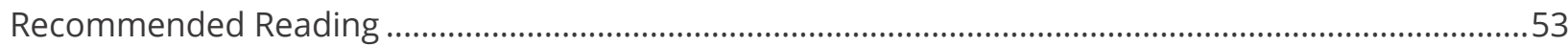

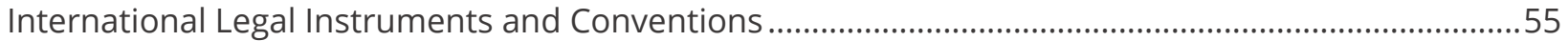

Annex 1: Questionnaire Used during the Interviews .............................................................................5

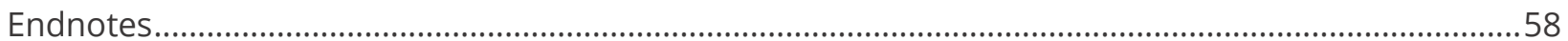




\begin{tabular}{|c|c|}
\hline AFIEGO & African Institute for Energy Governance \\
\hline AJWS & American Jewish World Service \\
\hline$A U$ & African Union \\
\hline BAWATA & Women's Council of Tanzania \\
\hline CSO & civil society organization \\
\hline CJGEA & Center for Justice Governance and Environmental Action \\
\hline DD Coalition & Defending Land and Environmental Defenders Coalition \\
\hline DPMF & Development Policy Management Forum \\
\hline EACJ & East African Court of Justice \\
\hline EU & European Union \\
\hline HRDs & human rights defenders \\
\hline IFI & international finance institutions \\
\hline ILC & International Land Coalition \\
\hline IPCC & International Panel on Climate Change \\
\hline IUCN & International Union for the Conservation of Nature \\
\hline KCDF & Kenya Community Development Foundation \\
\hline KFS & Kenya Forest Service \\
\hline LAPSSET & Lamu Port-South Sudan-Ethiopia Transport Corridor Project \\
\hline LERDs & land and environmental rights defenders \\
\hline LHRC & Legal and Human Rights Center \\
\hline HRDs & human rights defenders \\
\hline NCHRDU & National Coalition of Human Rights Defenders of Uganda \\
\hline NFA & National Forestry Authority \\
\hline NGO & nongovernmental organization \\
\hline NGONET & Ngorongoro NGOs Network \\
\hline OPDP & Ogiek Peoples' Development Program \\
\hline RRI & Rights and Resources Initiative \\
\hline SDG & Strategic Development Goals \\
\hline TPCF & Tanzania Pastoralist Community Forum \\
\hline UDHR & Universal Declaration of Human Rights \\
\hline UN & United Nations \\
\hline
\end{tabular}


UPDF Uganda People's Defence Forces

USAID United States Agency for International Development

UWA Uganda Wildlife Authority

ZLSC Zanzibar Legal Services Center 


\subsection{Context and Background to Criminalization of Land and Environmental Rights Defenders in East Africa}

As the demand for land-based investments in East Africa rises, alongside unprecedented growth in population sizes in some of the fastest-growing economies on the African continent, pressure on and conflicts over land and the environment are bound to increase. Indeed, land-related conflicts are now a common feature in the region, with disputes pitting governments, multinational companies, and local private sector actors against Indigenous Peoples and citizens generally. For every action, however, there is an equal and opposite reaction, as Newton's third law of motion teaches us. Where violations against people's land and environmental rights occur, resistance-both in form and in substance-can be expected. More often than not, that resistance is met with counter-resistance and pushback from the state and private capital interests.

Therefore, land and environmental rights defenders are, in more ways than one, the first line of defense in pushing back against land grabbing, destruction of the environment, and other forms of violations with respect to land rights. For that role, they pay the ultimate price. Some pay with their own lives, others with criminalization and victimization by the state and, sometimes, private business actors. One can see, for instance, that in East Africa, criminalization of land and environmental rights defenders is on a marked rise. This increase is not helped by the shrinking civic space in Kenya, Tanzania, and Uganda and the democratic rollback observable across the African continent. A confluence of these complex dynamics and patterns makes it important to continually monitor, study, investigate, and document the criminalization and victimization of land and environmental rights defenders in the region. It is against this backdrop that the International Land Coalition (ILC) and Rights and Resources Initiative (RRI) commissioned this research paper.

Global Witness defines land and environmental rights defenders (LERDs) as people who take a stand and take peaceful action against the unjust, discriminatory, corrupt, or damaging exploitation of natural resources or the environment. ${ }^{1}$ A community-based understanding of land and environmental rights defenders views them as members of a "collective." In that sense, therefore, a defender does not necessarily occupy a position of leadership, even within the context of the "collective," but he or she does exercise and assert the defense of land and environmental rights. In fact, in an upcoming study by Rights and Resources Initiative, a LERD is "defined by what it does and regardless of whether they self-recognize as such. He/she holds rights that enable him to exercise his work, such as freedom of expression, peaceful association and assembly, and access rights. It can also be a collective subject, such as an organized community, a social organization, an NGO, a legal person or a collective, a social movement or an ethnic people."

Accordingly, the role of LERDs in the consolidation of democracy, the rule of law, peace and control of institutions, and environmental sustainability cannot be overstated. That is because "they are the ones who have the local proximity, experience and knowledge of the problems that arise with the land and the environment. They are able to identify project impacts, often have a sustainable 
development vision that benefits communities, and if their voice is heard, unnecessary conflicts and risks can be avoided." ${ }^{3}$

The LERDs' role also involves the defense of collective rights, which are "a set of rights which the community is collectively entitled to benefit from. These rights are stated in various international and national legal instruments and everyone, including the indigenous peoples, are entitled to their enjoyment individually or collectively." ${ }^{4}$ Collective rights include the right to development; the right to a clean and healthy environment; and the right to access natural resources, which include forestry, wildlife, and water. ${ }^{5}$

In the RRI study, criminalization is defined as "the manipulation of the punitive power of the State, that is, the power of the State to include crimes in a criminal code. This is done in order to: penalize the conduct of defenders with ambiguous criminal rates, speed up trials against subjects and ignore procedural safeguards. Criminalization assaults defenders and hinders their work in defending collective rights; promotes economic sectors and is disseminated through the media." ${ }^{16}$ On the other hand, systematic violence encompasses all circumstances that put defenders at risk, "which are not isolated facts, but are presented on a recurring and similar basis, within the framework of structural contexts of exploitation of natural resources and socio-environmental conflicts." ${ }^{17}$

\subsection{The Many Forms of Criminalization of LERDs in East Africa}

Among the forms of criminalization of LERDs in East Africa are the following:

- Accusing LERDs of serious crimes without foundation or based on fabricated evidence

- Subjecting LERDs to distorted and unreasonably lengthy criminal proceedings and subjecting them to pretrial detention

- Misusing counter-terrorism laws and other national security laws against LERDs

- Conducting illegal arrests and arbitrary detentions

- Criminalizing the rights to free speech, participation in peaceful protest, and public assembly

- Using criminal, defamation, or libel laws to punish or silence LERDs

- Criminalizing organizations and human rights defenders who receive foreign funding or support, as well as labeling such entities or actors as anti-development and working for sinister imperial interests

Evidence available through a literature review shows that criminalization and victimization of LERDs in East Africa are on the rise. In the case of Uganda, for instance, notes that:

Human rights defenders (HRDs) have become critical actors in the promotion and protection of the rights of the affected communities and in the advocacy for proper management of the country's natural resources for the benefit of all Ugandans. HRDs have achieved these things by providing human rights education, holding government and the companies involved accountable for their actions and for providing timely compensation, providing legal aid to members of the communities, 
and, in some instances, pursuing legal remedies on behalf of the communities. At the national level, HRDs have focused on promoting transparency and accountability with respect to the management of petroleum and mining revenues. For this, they have become a target of threats, harassment, and intimidation by government agents and oil and mining companies alike. The challenge is that many of these HRDs are vulnerable because they usually become HRDs by accident, often without training and preparation for the risks they face. ${ }^{8}$

According to a 2012 study by DefendDefenders, HRDs working in the context of Uganda's oil and gas sector face significant risks to their personal safety and security, and their rights to freedom of association and assembly, access to information, and participation are frequently restricted. These risks and restrictions are confirmed in the most recent report of the Human Rights Centre Uganda, which observes that HRDs in the extractives sector are among those at the greatest risk, and that especially those in the oil-rich Albertine region have been targeted by the state. Relatedly, there is evidence of intensified criminalization and victimization of LERDs asserting the rights of Indigenous communities in Uganda such as the Acholi, the Benet, the Madi, and communities in Mubende district, as the country-specific case studies in this paper show in detail.

The situation in Kenya is no different. In 2017, the Center for Justice Governance and Environmental Action (CJGEA) observed that "These are very trying times for Kenyan activists, particularly those working in the area of the environment and human rights. Most human rights defenders working on issues of the environment and human rights are not professional activists, such as lawyers; the majority of them work at grassroots level and are people who rise up because of encroachment into their territories or environment. They respond to issues of pollution, displacement or limited access to natural resources such as rivers and land." ${ }^{\prime 9}$

In December 2018, Human Rights Watch and the National Coalition of Human Rights Defenders in a joint report noted that Kenyan police and the military were harassing and intimidating environmental rights activists in Lamu county, coast region. The 69-page report noted that at least 35 activists campaigning against the region's mega infrastructure and transport projects under the Lamu Port-South Sudan-Ethiopia Transport Corridor Project (LAPSSET) had faced threats, beatings, arbitrary arrests, and detentions. ${ }^{10}$ The plight of these activists reverberates with the lived experiences of community-based LERDs in Kenya. It signals a pattern of sustained and intensified criminalization of LERDs in the country, regardless of the nature of the land or environmental rights they seek to assert or the formations and platforms through which they find a voice.

In Tanzania, Indigenous communities such as the Maasai continue to be criminalized whenever they defend their land rights. According to DefendDefenders, "The Maasai peoples of East Africa have inhabited parts of what are now Kenya and Tanzania for centuries. They are known for their distinctive dress and pervasive pastoralist culture, centered on seminomadic cattle herding. When the Serengeti National Park was gazetted in 1959, many Maasai lost grazing rights in much of the Serengeti and Ngorongoro Crater, and at least 50,000 have since been evicted or displaced, according to some estimates."11 
Many Maasai settled in areas bordering the park, which has grown in size since its initial boundaries were drawn. On February 3, 2010, a group of Maasai pastoralists filed a claim against Tanzania Breweries and Tanzania Conservation Ltd, a Tanzanian subsidiary of U.S.-based Thomson Safaris. The group alleged that the companies, in league with corrupt government officials, had forcibly evicted them from ancestral land around Loliondo without free, prior, and informed consent, or compensation of any kind. Over the course of the case, residents of Mondorosi, Soitsambu, and Sukenya villages alleged that local homes were deliberately set on fire and that LERDs had been attacked and arbitrarily detained while accessing areas near the contested land. On October 28, 2015, an Arusha-based High Court ruled against the Maasai, setting a dangerous precedent and paving the way for additional conflict and human rights abuses on neighboring Indigenous land. In July 2016, several Maasai HRDs working on these issues were arrested near Loliondo, as was a lawyer sent to investigate the case after the HRDs in question were held for several days without charges. A year later, in August 2017, Tanzanian wildlife officials and Tanzanian security forces began torching Maasai homes near Loliondo, and by September more than 5,000 homes had been burned and 20,000 people left homeless, by some estimates. Although the Ministry of Natural Resources and Tourism said that the evictions were legally justified and claims of destruction exaggerated, 52 LERDs interviewed for DefendDefenders' report described it as the most violent eviction in living memory, leading to the arbitrary arrests of several LERDs. Many allege that since that time, a pervasive climate of fear has surrounded LERDs who have attempted to bring these issues to light, including police harassment and confiscation of travel documents. Nearly all respondents cited corruption as a major factor contributing to violence in pastoralist communities across northern Tanzania. ${ }^{12}$

In sum total, the criminalization of land and environmental rights defenders in East Africa, as in the rest of the world, is on the rise, and it largely pits both corporate and state power against LERDs (understood both in the individual and collective/community sense). Understanding the nature and source of this criminalization is an important starting point for devising mechanisms of addressing it and ensuring greater protection for LERDs in East Africa.

\subsection{Objectives of This Research Paper}

The objectives of this paper include the following:

- To gather data on cases of violence and/or criminalization of land and environmental rights defenders (LERDs) in Kenya, Tanzania, and Uganda

- To collect information on existing strategies and resources to address the criminalization of LERDs in East Africa

- To map organizations working on the issue at the local, national, and regional levels

- To understand the steps leading to violence against or criminalization of human rights defenders 


\subsection{Methodology}

This research project draws on the qualitative research method. Using this approach, the consultant undertook a desk review of both primary and secondary sources of literature. These included regional and international instruments for the protection of LERDs; the laws of Uganda, Kenya, and Tanzania; reports of the UN and African Union (AU) Special Rapporteurs on the Situation of HRDs; reports of reputable nongovernmental organizations (NGOs); and scholarly and newspaper articles.

\subsection{Interviews}

Drawing on this method, this research project adopted a semi-structured interview format. That format allowed for open-ended questions to the interviewees, with emphasis on the research questions that the project aims to answer and room for greater detail to be covered. A total of 28 LERDs, civil society actors, and government officials were interviewed across Kenya, Tanzania and Uganda. The interviews were conducted through face-to-face interactions where possible, email, internet-based applications WhatsApp and Zoom, and phone calls. The names of interviewees per country are listed in introduction of each country's section. Where anonymity was requested from interviewees for safety or other reasons, that request has been respected. An annex at the end of this report provides a sample of the questions that guided the interviews.

\subsection{Document Analysis}

The researcher reviewed and analyzed publicly available data, records, and documents relating to the topic. This review was achieved through reading and analysis of public documents such as human rights reports, public presentations, and scholarly research reports on the subject matter.

For this research project, review and analysis of documents was particularly instrumental insofar as it helped generate further questions for interviewees and verify information those individuals shared during interviews.

\subsection{Country-Specific Cases of Criminalization of LERDs in East Africa}

\subsection{Uganda}

\subsubsection{Introduction}

This section samples four cases of criminalization and victimization of LERDs in Uganda, with a focus on the Madi community of Zoka Forest, the Benet community in eastern Uganda, the Acholi community in Amuru (northern Uganda), and the communities in Mubende district (central Uganda). The lived experiences of LERDs as individuals and as collectives are captured, as is published material on some of the incidents. The following were interviewed: Dickens Kamugisha (Executive 
Director, African Institute for Energy Governance [AFIEGO]), William Amanzuru (Friends of Zoka), Regina Asinde, Sam Mucunguzi, Eron Kiiza, Eriya Nawenuwe, Henry Mutebe, Patricia Munabi, and several community members who requested anonymity.

\subsubsection{The state versus the Madi community of Zoka Forest}

Sitting on 6,145 hectares, Zoka Central Forest Reserve in the northern Uganda district of Adjumani is the only tropical forest in that part of the country and the last natural forest along the belt of the oilrich Albertine region. The forest hosts a significant portion of the world's bird and insect species, and hardwood trees such as mahogany can be found there. It has existed since the 1940s, and the Madi community of Uganda's West Nile region has benefited from the natural habitat for decades.

It is important to point out that there is no conflict between the government of Uganda or any other party and the Madi community over land ownership or even boundaries of the forest. The tension that continues to exist arises from the fact that members of the Madi community have challenged attempts to degrade the forest by people reportedly enjoying state protection. In other disputes in many parts of Uganda, as is the case with Amuru and the Benet community highlighted in this study, the state or businesspersons are contesting land ownership and boundaries, but for the Madi community, this is not an issue. In fact, the contention arises from the fact that some members of the Madi community have emerged as LERDs opposed to the forest's degradation. This, therefore, is a case of LERDs being victimized for protecting the environment. For that, they are paying the price as both the state and private citizens with vested interests in the forest pile pressure on them.

In 2014, residents of Itirikwa and Yukusinjoni, Adjumani's two subcounties that straddle the forest, started to notice peculiar movements in and out of the forest. What started as suspicious activity in the thickets mutated into actual and verifiable evidence that massive destruction of the forest was happening. Illegal logging and lumbering were taking place, and the charcoal business was booming. Agents of Uganda's security organizations, including the Uganda People's Defence Forces (UPDF) and the Uganda Police Force, were cited by residents around the forest, who said the agents were facilitating illegal activity there. The district local government officials were mute. There was suspicion that officers of the National Forestry Authority (NFA) - a statutory body established by Uganda's parliament to safeguard natural endowments such as Zoka - were involved in what appeared to be a closely knit ring of military-business-political interests.

In 2016, two concerned residents-William Leslie Amanzuru, then age 34, and John Onzima, then in his early 20s-challenged the destruction of the forest. They questioned the silence of the district officials but were ignored. The two men mobilized the Madi community to form an online group on the social media site WhatsApp and called their association Friends of Zoka. To this group, they added district officials of Adjumani, including the area officials from national bodies such as the National Forestry Authority and the Ministry of Water and Environment, as well as security officers and local civic, political, and opinion leaders. Amanzuru and Onzima would take pictures of trucks 
leaving the forest, loaded with timber or charcoal, and would share those pictures in the group, demanding answers from whoever cared to respond.

The two men started to investigate the power structure behind the forest's destruction and to put names and faces to the shadowy characters profiting from its degradation. A community group in the name of Friends of Zoka was opened on Facebook. The group was blocked by unknown actors. The men opened another group. It too was blocked mysteriously, and none of the page administrators could post anything. Unrelenting, the group opened yet another page, and that third page was not blocked.

In an interview for this research paper, William Amanzuru said, "We would go to the forest with our cameras, record military men loading the logs, timber and charcoal on trucks and present this evidence to the district officials. Eventually we met the Speaker of Parliament of Uganda and petitioned her to look into the matter. Four ministers were sent to the forest to engage the community in 2016, they got facts and wrote different things in their report, negating what was on ground and the sentiments of the community."13

At that point, the men behind the flurry of illegal activity in the forest became impatient with the community's civic leaders and opted to silence Amanzuru. He claimed in the interview that he was threatened and offered bribes twice, including an offer of "a decent house" and about US $\$ 4,000$ by a logger and an official working with NFA. He turned down both offers and asked the two individuals to simply preserve the forest by desisting from the destructive path they were taking. They did not relent. Amanzuru's family became the next target. His rented apartment in Kampala city was broken into thrice in 2018, and his up-country home in Adjumani was broken into twice and was swept clean on May 18, 2018. An intelligence officer working in Adjumani tipped him off about a threat to abduct his two sons and two adopted daughters from a school in Adjumani. Those school-going children have since been relocated to the eastern part of the country.

Amanzuru was warned by the intelligence operative, "You are stepping on big people's toes. Take your children out of Adjumani for their own safety."

More was yet to come. From trumped-up charges including theft, robbery, and treason, Amanzuru now finds his freedom limited as he spends his days out on a police bond, which is extended at the mercy of police officers who have failed to adduce evidence implicating him in any of the crimes of which he is accused. He has even been accused of rebel activity and staging roadblocks in the district. His colleague Onzima was beaten to near death in 2017 while on journalistic duty, an incident that is attributable to his stance on Zoka Forest. In addition, two volunteers in their early 20s who work with the team at Friends of Zoka have not been spared ostracization and stigma from sections of the community that have resigned to fate.

The story of Amanzuru and Onzima is a microcosmic representation of the criminalization and victimization of the wider Madi community in its effort to salvage the forest from highly connected 
business interests. The community whose sustenance is heavily reliant on the forest is about 10,000 people, whereas the district has a population of up to 200,000 . For decades, the community has relied on the forest for herbal medicine due to thin modern medical treatment facilities on the ground in rural areas, and for food, firewood and wider biodiversity benefits from the ecosystem of the forest. Defense of the forest against depletion is therefore a life-and-death matter for this community.

Accordingly, the clash of business and community interests has put the Madi on edge. In at least 10 interviews conducted for this research project, leaders and members of the community expressed both the anxiety and the fear that have become commonplace in the past five years.

"We are intimidated, we know that they are watching our movements and there is a lot of surveillance and intelligence gathering within the community. We don't even know who is with us or against us. As a community, we are living in extreme fear," a community member and mobilizer who preferred to speak on condition of anonymity said in an interview. ${ }^{14}$ It goes without saying that women face greater risks and threats in this community. This can be explained in part by the fact that Uganda, like many parts of Africa, is still a society where patriarchy is prevalent, and the odds are stacked against women LERDs who put up a formidable resistance in circumstances like those of Zoka.

This gender dimension deserves retrospection because as the UN High Commissioner on Human Rights, Michelle Bachelet, has observed, "The rise in feminist organising, including to protect land, environment and decent work, has been met with a toxic mix of online abuse, physical attacks and sexist rhetoric by political leaders around the world."15 It goes without saying, therefore, that women's lived experiences as land and environmental rights defenders are differentiated by their sex or gender. The plight of female members of the Madi community was captured by one female activist who shared the following in an interview for this project: "Our men expect us to focus on bringing up our children and taking care of the home while the men depleting the forest that we are resisting as a community don't expect women to be at the frontline, and our leaders at the community level raise eyebrows when they see us attending meetings organized to save the forest. From all sides, we are stigmatized."16

The leader of this community's efforts to save the forest, Amanzuru, noted that the female activists in the community prefer to work behind the scenes through such interventions as knowledge sharing and availing resources within their limits to the men taking the lead in the fight for the forest.

"In fact even in media interviews they prefer not to be quoted directly because they take a lot of flak and the land grabbers see them as a soft target for intimidation," Amanzuru shared in a separate interview for this project. These nuanced forms of discrimination against women feed into already existing normalized patriarchal sentiments on the role of women in society with respect to property 
rights and ownership. Such discrimination positions women as second-fiddle actors in the defense

of their own land and environmental rights. It is never innocent, but rather a well-choreographed tool of oppression deployed by the state and corporate interests in the victimization of LERDs.

Despite these setbacks, the community continues to soldier on. On March 18 to 22, 2019, as Uganda marked its annual Water and Environment Week, four environmental activists walked $470 \mathrm{~km}$, starting their journey at the environmental ministry headquarters in Kampala and traveling to Adjumani in a bid to raise awareness about encroachment on Zoka Forest. The 15-day walk, supported by Care International, was undertaken by Amanzuru, Solomon Agwe, Geofrey Alule, and Ayiga Joseph under the auspices of the group, Friends of Zoka. It is noticeable that women are missing from this list of participants because of the gender-specific challenges they face as LERDs.

On May 6, 2019, the European Union (EU) delegation to Uganda awarded Amanzuru the EU Human Rights Defenders' Award in recognition of and appreciation for his resilient efforts to salvage the forest. In November 2018, the organization DefendDefenders recognized him as the Human Rights Defender of the Month.

Despite these interventions from different quarters and noble recognitions, the Madi community still lives in fear, the forest continues to get depleted, and Friends of Zoka remains the lone consistent voice as other nongovernmental organizations have been silenced. Meanwhile, government bodies charged with protection of the natural habitat are accused of complicity in its destruction.

Friends of Zoka identifies itself as a community group started by community members in Adjumani District concerned with degradation of the forest. Its main objective is to provide advocacy and lobbying on management of Zoka Central Forest Reserve and broader management of environmental challenges in Adjumani District. The group advocates to promote the protection, preservation, conservation, and sustainable management of the forest and the bigger environment in Adjumani, West Nile, and Uganda, "in recognition of the important role that forests play in promoting biodiversity, mitigating climate change, and supporting the livelihoods of local communities."17

The group has since received support for capacity building from the National Coalition of Human Rights Defenders - Uganda, the Human Rights Centre Uganda, American Jewish World Service (AJWS), and the International Union for Conservation of Nature (IUCN).

\subsubsection{Mubende Land Evictions and Criminalization of Uganda's LERDs}

Between late 2016 and October 2017, Witness Radio, an NGO, documented more than 100 landrelated conflicts in the district of Mubende. ${ }^{18}$ The organization's objective is to understand the magnitude of land forcefully taken through evictions and the impact of that activity on Indigenous Peoples' livelihoods. It is instructive to point out that the tension between the communities in 
Mubende and the state or businesspeople (or both) arises from disputes over ownership of land, itself a result of a complex tenure system and a law that recognizes the land title as the conclusive evidence of land ownership. With many residents in the district not possessing titles to their land but laying legitimate claim to the same, conflicts arise as some unscrupulous actors take advantage of the situation. There are also reports of land grabbing and failure to follow the law during evictions, as well as politicization of land issues by local leaders in some cases.

Witness Radio has established a register of land grabbing cases in Mubende; developed a database of individuals and companies behind land grabbing; and documented all forms of human rights abuses committed against Indigenous communities by a cartel of economically powerful and politically connected individuals during the scheme of grabbing poor Ugandans' land.

Mubende district, in central Uganda, is one of the country's oldest districts, dating as far back as 1905. In the recent past, the district has been a hotbed of land-related conflicts pitting Indigenous communities against multinational capital and governmental forces. The 2014 National Population and Housing Census estimated the district's population at 684,348 with 151,100 households. Of those households, 119,709 (79 percent) depend on subsistence farming as their main livelihood.

Between November 2016 and October 2017, Witness Radio documented cases of land grabbing and forceful eviction of sitting tenants and bona fide occupants from land totaling up to $1,975,834$ hectares. ${ }^{19}$

The organization's findings indicate that a majority (60 percent) of the evictors/perpetrators were local businesspersons, followed by foreign investors with 6 cases ( 24 percent) and government with three cases.

More than 265,502 households, the organization reported, "have been left homeless and landless with nothing to feed on since majority community members have been involved in subsistence farming. The land to many was giving them a sense of belonging as their graveyards were being hosted on the same land. Families have not only lost land but properties worth billions of shillings from houses that have been burnt to ash, vehicles and motorcycles looted or burnt in the process of eviction. Household belongings were also lost to businessmen and their casual workers." ${ }^{20}$

Public institutions such as the police, the Uganda People's Defence Forces, the office of the Mubende District Resident Commissioner, the Mubende District Land Board, prosecutors, and courts of law mandated to protect Indigenous communities and their properties have been faulted for protecting workers of businessmen who have committed gross human abuses. Such abuses have ranged from gang rape to torture, participation in illegal arrests and detentions, overseeing the use of ungazetted detention centers to imprison community leaders organizing communities to oppose illegal land evictions, and malicious prosecution, among others. 
According to Witness Radio 24 out of the 25 cases it documented were forceful evictions, affecting more than 186,000 households.

The findings by the NGO suggest that more than 70 percent of prison inmates in Mubende are in prison over land-related conflicts. Whereas the charges appear to be independent criminal charges on the surface, in a real sense "these cases have connections to the unchecked land conflicts from the communities. The charges range from aggravated robbery [to] rape, defilement, murder, [and] theft among others." 21

The trend of the evictions monitored and documented by Witness Radio shows a worrying trend in which judicial processes, especially court orders that have been obtained by the victims and LERDs, are blatantly ignored by the perpetrators.

Additionally, the NGO observes, "the perpetuators have been emboldened to deliberately disregard lawful procedures to acquire land while knowing at the back of their minds, that even if communities go to court, the authorities in the district will not enforce a court order."22

In an interview for this paper, human rights lawyer Eron Kiiza noted that in the cases he has handled in Mubende as a human rights advocate, all the accused have involved LERDs.

"There are two local councilors who do not claim any ownership of the land in question but chose to defend the rights of the people to that land. They were arrested alongside other land rights defenders who doubled as claimants to the land," Kiiza shared in the interview. The investors in Mubende, he contended, did not follow the legal process of evictions as stipulated in the United Nations Basic Principles and Guidelines on Development-Based Evictions and Displacement, ${ }^{23} \mathrm{a}$ benchmark for evictions around the world. To the extent that evictions were conducted without due regard to human rights, "some members of the affected communities stood up to the companies, only to face the wrath of the state."24

The Uganda Police Force and other security agencies, the lawyer noted, "terrorized the villages, and whichever LERD reported a matter to police pertaining [to] that issue was instead arrested. It is a template now; security forces will always back the investor and try to break the back of resistance of the land rights defenders."

This pattern, Kiiza observes, points to criminalization and victimization of LERDs in Uganda taking the shape of state capture, with institutions of the state such as the army, police, court system, and local political leadership being subservient to the interests of highly connected businesspeople.

"I have been harassed with criminal charges which are still standing. One time they blocked clients from accessing court so that the public could not witness the hearing. I can't sleep in Mubende when handling land-related cases there because I don't feel safe," Kiiza shared, adding, "Those (landrelated cases) consume all your time as a lawyer; you forego many other suits and then you are 
traumatized. You feel as helpless and hopeless as the situation you are dealing with. It takes a toll on your mental health, time and resources since you cannot attend to private clients. I have been branded an opposition lawyer; that I have [a] vendetta against policemen and that I am a politician hiding under the law."25

Kiiza notes, "Of course, the state is subservient to private capital. There are private individuals and companies that order District Police Commanders and Regional Police Commanders around. That is state capture. They (government officials) have unwavering loyalty to business interests and do precisely as told by them. Local leaders and LERDs are picked up, detained or bribed into silence."26

At the time of writing this research paper in November 2020, the contested land in Mubende was under occupation and possession of investors because the claimants and the LERDs in the area were thrown out of the villages, evicted forcefully, and some 28 of them detained in prison. They were accused of murder, attempted murder, and robbery. Their crime, their lawyer argues, is challenging illegal takeover of their ancestral land and daring to defend their land rights.

Regina Asinde, the country director for Land and Environmental Rights Watch Africa, observes that in parts of Uganda such as Mubende, "Most HRDs are intimidated, put under surveillance (both physical and digital), arrested and even brutalized by security agencies. A number of defenders have been warned off some campaigns they were spearheading while others have had their homes broken into and their property destroyed. In Kiryandongo, the land defenders have been arrested and others killed while in custody. Communities that have defended their land like those in Mubende and the community of Benet have been subjected to continued raids on their property with their women getting raped, others killed and their property (houses and gardens) burned down."

Dickens Kamugisha, the executive director of the African Institute for Energy Governance (AFIEGO), says that victimization and criminalization of LERDs in areas such as Mubende speaks to the wider political challenges the country is grappling with. Among those challenges are reduced space for NGOs critical of the excesses of the state and corporate power; media; opposition politics; and a general malaise in the body politic and citizen apathy in the country. The few LERDs who dare to speak out face a tough time. The others have taken to the politics of survival and retreated from the arena.

In interviews with 10 community-based LERDS in Mubende for this research paper, it became clear that the communities feel emasculated by the power of the state and the corporate interests it backs. This, as one local leader noted, "happens because our own elected leaders who are supposed to represent and defend our interests as an indigenous community claiming rights to the land either abandon us when we need them most or remain lukewarm. Who then can we run to?"27

The plight of the people of this community would ordinarily catch the eye of NGOs, but as civic space shrinks in Uganda, the target of criminalization and victimization shifts to those organizations. One 
of those NGOs is Witness Radio, whose leaders, in interviews, aver that the pressure mounted on the organization under the country's restrictive NGO legislation is intense. Consequently, "We have to be extra careful in how we do our work as land and environmental rights defenders. There is anxiety each time we go to the field, and we cannot tell what tomorrow looks like."28

The Mubende case presents two dimensions to the situation of LERDs in Uganda, with communitybased organizing to defend land rights being under attack as much as NGO-based organizing to achieve the same objective. In effect, whatever form and shape such organizing takes, one is bound to run into trouble with the authorities.

\subsubsection{The Case of Amuru Community versus a Sugar Baron}

For more than a decade now, there has been friction between the Acholi community in Amuru District (northern Uganda), Madhvani Group of Companies (one of East Africa's biggest sugar companies), and the government of Uganda. The crux of the dispute is a 10,000-hectare chunk of land with proximity to the Nile River and the border between Uganda and South Sudan. According to K. P. Eswar, the Madhavani Group's corporate affairs director, the Madhvani sugarcane project in the north was first hatched in the 1960s, before President Idi Amin expelled Asians from Uganda.

“We wanted to give back to the people of the north since the region provided us labour. M

ost of the workers at Kakira in Jinja (eastern Uganda) where we have our factory are from the north. When we returned to business in 1985 as Asians were allowed back to Uganda, we identified that place considering things like rainfall and accessibility," Eswar said in an interview for this research project. ${ }^{29}$

In 2006, the company expressed interest in the land and got a nod from the government of Uganda and the Amuru District land board. The community has, however, resisted attempts by both the government and investors to get the land.

In an interview for this project, a local area member of parliament, Gilbert Oulanyah, claimed, "I am very sure since 2007 so far at least \$120 million [about U Sh 500 million] has changed hands between Madhvani and local politicians, the district land board of Amuru, and security agencies, all to see to it that the land goes to the company without paying a higher price that negotiating with the local people would come with." 30 


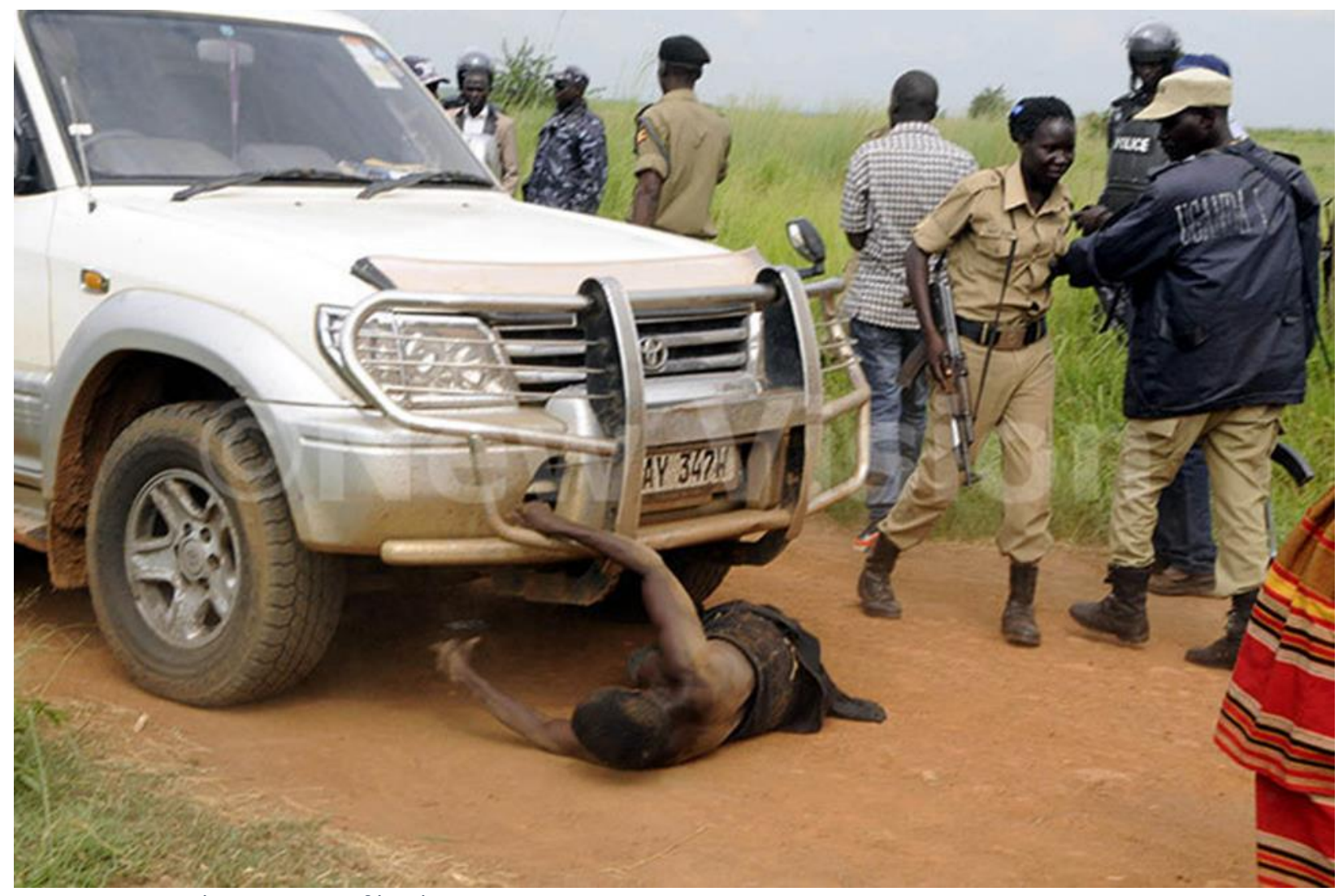

Women protest the surveying of land in Amuru District. (Source: New Vision.)

Eswar disputes this claim: "That is not true. How can Madhvani do that? We don't do such things. Around 2007 we approached then Gulu district before Amuru district was carved out of it and expressed interest in the land. We met the district council, took (members) from that region to our main plant in Kakira and told them we want to replicate it in Amuru. They liked the idea, and the district land board gave us a lease offer for 10,000 acres as opposed to 20,000 because they didn't have [a] mandate to give out such land. We paid a premium of U Sh 230 million in 2007, including ground rent. As we waited for the land title, the matter went to court and the judge ruled in favor of the district land board, the community appealed, and we await the decision of court of appeal. We also await our land title from ministry of lands before we go on site." ${ }^{11}$

Article 237 (1) of the 1995 constitution of Uganda states, "Land in Uganda belongs to the citizens of Uganda and shall vest in them in accordance with the land tenure systems provided for in this constitution." Notwithstanding that clause, the article 237(a)(1) provides, "the Government or a local government may, subject to article 26 of this Constitution, acquire land in the public interest; and the conditions governing such acquisition shall be as prescribed by Parliament." 


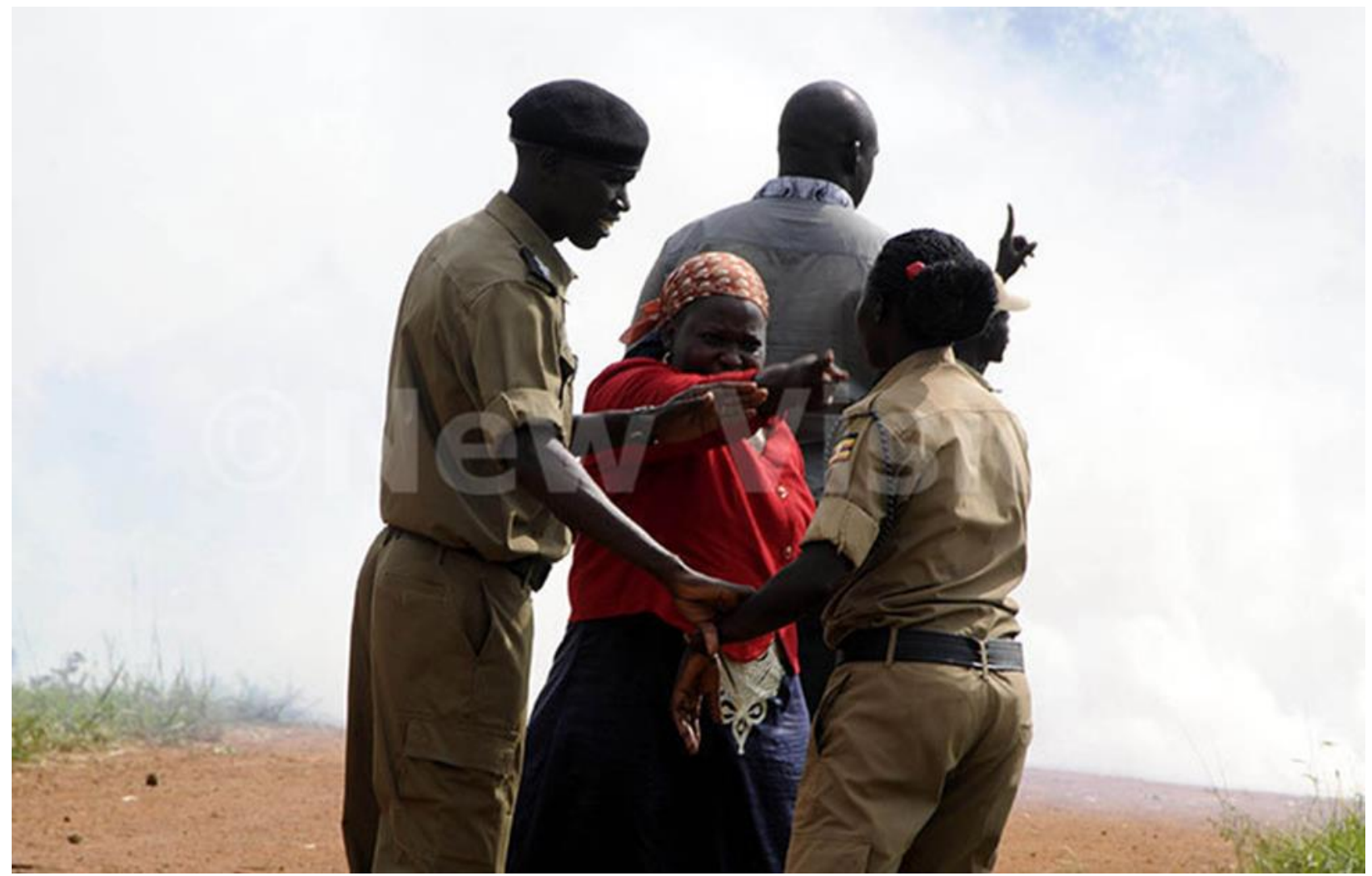

A woman demonstrator faces off with police officers during a protest in Amuru in 2017. (Source: New Vision.)

Article 241 spells out the functions of district land boards, which include "(a) to hold and allocate land in the district which is not owned by any person or authority; (b) to facilitate the registration and transfer of interests in land; and (c) to deal with all other matters connected with land in the district in accordance with laws made by Parliament."

The land in question is in the areas of Kololo, Lakang, Bana, Omee, Lujoro, Lwak Obito, and Pailyech, the subject of civil appeal 123 of 2012 in Uganda's court of appeal. The dispute over this land is another case of community-based land and environmental rights defenders on a collision path with corporate interests and the state. Accordingly, the members of the Acholi community in Amuru interviewed gave testimony to continuous criminalization and victimization of LERDs in the area, with cases of enforced disappearance-and, in some instances, deaths of community members seen by the authorities as opponents of the project-becoming the new normal.

“The biggest threat is that government intends to evict us. We will die here, they say we are recruiting rebels but they don't tell us who the rebels are and which rebel group it is, they have arrested Local council officials, how did we become rebels? We have hoes not guns," said Ochaka Lokrom, 34, a farmer in the area, adding that, "If they want to bomb us, let them do it. God will help us." ${ }^{32}$ 
Charles Opio and Patrick Okullo, residents of the area, were arrested in December 2017 and remain in detention over unclear offenses. Their peers suspect that the two were arrested because of their outspoken criticism of the project. For the population of 11,000 people in these sparsely populated areas, every day is life on the edge. In 2017, one young man drowned in the Nile River as security officers came upon a raid deep in the night. Such raids are commonplace as cycles of intimidation continue unabated.

Land disputes like those of the Amuru community in the northern part of Uganda, which until 2006 was ripped apart by a rebellion of the Lord's Resistance Army, are common. Cases of criminalization and victimization of Indigenous communities that dare to assert their land rights are also common.

In August 2017, women in Amuru dominated the news headlines when they carried out a topless protest in defense of their land. The government-owned newspaper, the New Vision, reported that scores of women protesters stripped, exposing their breasts.

"The Police used teargas in the air to disperse the angry residents who blocked a road at TeakuteuKololo Market, seven kilometres to Bomben, where the minister for lands, Betty Amongi, was scheduled to launch a survey exercise," the report said.

This incident, once again, brings into sharp focus the dynamic of gender in land rights defence and the different forms of expression of protest available to different LERDs in Uganda. To rural women like those of Amuru, "sometimes the only instrument of opposition to oppression is our naked bodies. It is dehumanizing but that is the only weapon we have," as one of the LERDs put it.

\subsubsection{The Benet vs the State}

Uganda's Benet community, sometimes called the Ndorobo, Mosopishiek or Ogiek have settled in the forest and moorland on Mt. Elgon for an estimated period of 500 years, concentrated in presentday sub counties of Kwosir, Kitawoi and Benet in the Eastern Uganda district of Kween. According to the Benet, their rangelands stretch from Sironko river in the West eastwards across Suam river into Kenya, then again past river Lwakhakha back into Uganda as far as river Manafa (Mutambukah, 2020).

In 2013, a census was conducted of the Benet people in the three districts of Bukwo, Kween and Kapchorwa. It was found that they numbered 8,500 with the majority of them $(4,500)$ living in Kween. In the 2014 national census, it was established that in Kween district an average household was made up of 5.2 members meaning that the Benet in the district would approximately come from 865 households (Mutambukah, 2020).

Like other indigenous peoples in East Africa, the Benet have not been spared the wrath of land and environmental related conflict with the state and private individuals seeking to dislodge them from ancestral land whose ownership claim they date as far back as centuries. Without clear documentary 
evidence to prove ownership of the land, the Benet community are left at the mercy of the state which seldom protects them.

The genesis of the conflict between this community and government of Uganda is a 1993 decision by the state to gazette land occupied by the Benet around Mt. Elgon. Whereas the Benet could stay within the precincts of the forest, strict rules were introduced, restricting cultivation and animal grazing.

Mutambukah writes that, "A series of events gradually reduced the rights of the Benet who were not only oppressed by government but also suffered even more from oppression meted on them by other communities in the region," (Mutambukah, 2020: 2).

Uganda is party to several international protocols. One of those protocols-the Voluntary Guidelines on the Responsible Governance of Tenure of Land, Fisheries and Forests in the Context of National Food Security (VGGTs) —obliges states, among others, to recognize the social, cultural, spiritual, economic, environmental, and political value of land to Indigenous Peoples and other communities with customary tenure systems.

The Benet community mobilized to defend its land and assert its ownership of the part of the forest and mountain gazetted by the government. With support from civil society organizations, a suit was successfully lodged in Uganda's High Court, which ordered the degazetting of land the government had accused the Benet of encroaching on. ${ }^{33}$

Three community members interviewed for this research project noted that despite this court victory, government of Uganda agencies (chiefly the Uganda Wildlife Authority) have continued to criminalize and victimize members of the community who dare to assert the land rights of the Benet.

"The park rangers confiscate our animals and intimidate leaders of the community who stand up to the authorities. We live in fear like foreigners and second-class citizens in our own country," a member of the community observed. ${ }^{34}$

David Mande, a resident of Kween district, told local media in October that since the government ordered the eviction of the Benet people from their ancestral land, the community has gone through extreme difficulties at the hands of park rangers, including raping women and beating and shooting of men.

"Over the years the Uganda Wildlife Authority (UWA) has terrorized this community by burning homes, beating and killing people while several others have been arrested for grazing their animals in the park and trying to demand for their land," Mande shared with local media. ${ }^{35}$ The community demands that the government honor a court order for resettlement of the community on 2,250 hectares of land that was degazetted from Mount Elgon National Park. 
The plight of land rights defenders among the Benet community speaks to the lived experiences of East Africa's Indigenous Peoples and their struggle to assert land rights against the backdrop of increased demand for land and rising tensions between states and such communities.

\subsubsection{Conclusion on Uganda}

The four case studies from Uganda present noticeable patterns about the state of LERDs in the country. In all the cases, the Ugandan state either is the lead abuser and violator of rights of LERDs and communities or is aiding and abetting the same. Uganda's role in these cases is partly attributable to corruption and a dysfunctional state machinery incapable of adjudicating disputes between communities and investors fairly and efficiently. These factors are particularly visible in the cases of Mubende and Zoka Forests, as well as in the Amuru land dispute and the Benet community case, where communities are rendered helpless as state institutions cannot guarantee them a minimum level of protection. The few LERDs who dare to challenge the status quo are easily identified, isolated, and victimized. Sometimes the courts do issue judgments and rulings in favor of communities. However, the courts are rendered docile as court orders are ignored by law enforcement agencies. Those agencies are accused of being captured by private commercial interests or simply acting out of impunity, thanks in part to a culture of disregard for human rights and freedoms. These vulnerable communities and LERDs are left at the mercy of NGOs and a few progressive politicians who amplify their plight. Conclusively, it is noticeable that where checks and balances are dysfunctional and power-be it corporate or state-is unchecked, an atmosphere conducive to victimization and criminalization of LERDs obtains in Uganda unabated and is rising.

\subsection{Kenya}

\subsubsection{Introduction}

The three case studies from Kenya were conducted between October 12 and November 18, 2020. The case studies look at how criminalization and victimization of land and environmental rights defenders in Kenya are manifested. In so doing, the section teases out the source and nature of conflict facing LERDs as communities and as individuals, as well as organizations that support them. The choice of the case studies was informed by several factors, including prominence of the cases; recommendations from actors within the land and environmental rights sector; availability of sources for interviews within the time limits of the study; and ease of verification of available literature on said cases. The key stakeholders interviewed for the Kenyan case studies are Ole Ntiaput, Nalengoyo Ole Torome, Ikal Angelei, Patrick Langat, Jonathan Shaa, Yator Kiptum, and four others who preferred to speak on condition of anonymity. To achieve fairness and balance, efforts were made to get the side of the story of parties and the government against whom allegations were made. To do so, their publicly available statements and responses to the issues raised against them were captured. Because of time constraints and difficulty of access, it was not feasible to speak 
directly to companies or state agencies the interviewees mentioned, so their side of the story was obtained largely through literature review.

\subsubsection{The Case of the Maasai in the Kedong Valley}

A rift between the Maasai on the one hand and the Kenyan government and Kedong Ranch Ltd ( $a$ private company), on the other, is a microcosmic representation of the nature of criminalization to which Indigenous communities in Kenya are subjected as they defend their land rights.

For context, Kedong Ranch Ltd is a private company that has had the lease for Kedong Valley since 1950, when it obtained the lease from the colonial government. Fifty years after Kenya's independence, the community remains restive as its status on the land is challenged. Interviews conducted with four members of the Maasai community point to intensified criminalization and victimization of LERDs in the Kedong Valley.

In the course of research for this paper, the author gained access to a letter written by the International Network for Economic, Social and Cultural Rights to the President of Kenya, Uhuru Kenyatta. The letter was written on July 9, 2020, to express concern regarding the recent attempts to criminalize and intimidate human rights defender Nalengoyo Ole Torome for defending the land of the Indigenous Maasai communities in Kedong Valley.

According to credible information cited in the letter, on March 21, 2020, members of the Indigenous Maasai Kitet/Suswa communities protested the fencing of their ancestral community land that was carried out by employees of the Kedong Ranch Limited under the protection of the police. On June 15, 2020, community member Nalengoyo Ole Torome was summoned to the police station to be informed that he had been identified by witnesses as having thrown rocks during the protest and was being charged with causing bodily harm and disturbances. On June 26, 2020, Torome was once again summoned to the police station under the guise of having to collect some documents there. He was arrested upon arrival, and he was held until June 29, 2020, when he was released on bail after pressure from the community. Torome has stated he was not present at the protest on March 21,2020 , and that the charges against him are false (as per the the letter).

Since Torome's release on bail, the harassment against him has continued. Police visited his home looking for him on Wednesday, July 1, and Friday, July 3, 2020, the second time allegedly accompanied by officials from Kedong Ranch Ltd. Community members are uncertain about the reasons for these visits, but they fear further retaliation against Torome.

As a member of ESCR-Net member organization Narasha Community Development Group and a leader of the Kitet/Suswa community, Nalengoyo Ole Torome has been involved in the struggle for the ancestral community land of the Maasai since 2010, representing the Kedong community. 
In documents provided to the consultant during the course of research for this project, the organization expressed concerns. It stated that it was concerned that the charges against Torome are attempts to intimidate him and the community and to discourage legitimate human rights work to protect the rights of Indigenous Maasai communities to free, prior, and informed consent and self-determination, including in relation to their ancestral community lands.

Even more, one document avers, "It is further concerning to note that these events appear to be taking place in a context of widespread criminalization, harassment, intimidation and other attacks on human rights defenders, including rural land rights defenders in Kenya." ${ }^{\text {"36 }}$

The recent incident is taking place in the context of an ongoing conflict related to the ancestral community land of the Indigenous Maasai community, now known as the Kedong Ranch.

In an interview for this research paper, Ole Ntiaput, who identified himself as a livestock farmer defending the community's land rights, observed that "the Maasai have suffered massive land dispossession dating back to colonial times and the practice has continued under postindependence governments. Kedong Ranch Limited, founded by colonial settlers, had established a ranch on the land before Kenyan independence and are currently title holders, while the Maasai claim ancestral ownership of the land." ${ }^{137}$

Ntiaput has been on the receiving end of harassment, just as the wider community for whose interests he advocates has been. In his interview, he noted that victimization of the community started after the signing of an agreement in May 2019 between members of the community, whom he accuses of being compromised by the company, and Kedong Ranch Ltd. The essence of that agreement was to have the community withdraw its appeal to the Court of Appeal in exchange for 4,000 acres and K Sh 10 million. ${ }^{38}$ Ntiaput, a plaintiff (now appellant) himself, was one of the community members who objected to this suspicious consent. For that, he and the community have had to pay the price.

During the interview, the land rights defender said: "They (Kedong Ranch Ltd) are digging trenches along the land to suffocate the people because they won't have an exit and entrance out of the land. In fact, recently a child fell into the trench and died. They are also using threats and intimidation, arresting members of the community and threatening to arrest those who continue to oppose their plans. The police brought to guard the land do not have number plates on their cars so they cannot even be identified." ${ }^{\prime 39}$

Ntiaput further noted that "the trench was dug to force the customary owners of Kedong off their land by closing off their access to waterpoints, the health centre, shops and grazing grounds. Roads were left open for a while, but on September 29th, 2020, the purpose of the trench became clear. The bulldozers came in and closed off the road to where Lilly's family [customary owners] lives." 
In 2015, Ntiaput explains, the High Court ruled in favor of Kedong Ranch Ltd, prompting the community to appeal to the Court of Appeal, but "as we await the decision of the court, the land has already been concessioned to various projects including a dry port and several geothermal plants, Akiira 1 and Olkaria V and VI."

The International Network for Economic, Social and Cultural Rights argues that these concessions have been affected without meaningful consultation of the Maasai communities and in violation of their right to free, prior, and informed consent.

According to ESCR-Net member organization International Accountability Project, "these projects have already raised concerns relating to serious human rights and environmental violations, resulting in the withdrawal of funding by the European Investment Bank in late 2019. The projects have led to the repeated, forcible displacements of Maasai communities. These displacements have involved the destruction of houses and property, as well as inhibiting the Maasai communities from engaging in their traditional way of life."

Ntiaput and three other community members interviewed for this research but speaking off the record contend that their efforts to rally both the community and civil society formations to challenge the concessions have earned them stigma from the state, which resorts to labeling them as "anti-development" and "enemies of the state and the people." To break the spirit of the community, on October 12, 2020, the Kedong Maasai chairman, Raphael Kerenke, was arrested under unclear circumstances, harassed, and taken to Nakuru despite the fact that there are a police station and a high court in Naivasha.

On November 18, 2020, Narasha Community Development Group, together with Indigenous Peoples Rights International, reached out to Katrin Hagemann, deputy head of the Delegation of the European Union in Kenya. They did so to bring to the EU's attention the recent criminalization of two Indigenous leaders, Raphael Kerenke and Nalengoyo Ole Torome, and the continuing attacks on the Maasai peoples in Kedong Valley.

Jackson Shaa, executive director of Narasha Community Development Group, shared in an interview for this research paper that Torome was arrested on June 26, 2020, and Kerenke on October 12, 2020. Torome has since been released on bail (June 29, 2020), as has Kerenke (October 13, 2020). Torome is charged with causing bodily harm and disturbances, and Kerenke with attempted assault. Both are Indigenous human rights defenders working on defending the collective rights of the Maasai peoples to their land and natural resources in Kedong Valley.

During an interview for this research project, Shaa said, "We believe the arrests and charges against [Torome and Kerenke] are attempts to discourage them from their legitimate demands for protection and respect of their individual and collective rights, including pushing their communities to cower in fear and silence in relation to the land disputes in Kedong Valley. Both of their cases are ongoing." 40 
Additionally, according to Shaa, on November 3, 2020, the Kenyan police attacked the church in Kedong Ranch to stop an ongoing village meeting and came back later that same day to demolish latrines. The community believes these outright intimidations were done to force the village Indigenous leaders to present themselves and risk getting arrested.

The ongoing land ownership cases against the Kedong Ranch involve 4,000 Maasai families, with a total population of 35,000 individuals at risk of being further dispossessed from their lands. The construction of the dry port has already caused forceful eviction of 21 families, who were left homeless after their homes were demolished in December 2019.

The Constitution of Kenya guarantees the protection of minorities and marginalized peoples, as do the African Charter on Human and Peoples' Rights and other international conventions that Kenya has ratified. Among those conventions are the International Covenant on Civil and Political Rights; the International Covenant on Economic, Social and Cultural Rights; the International Convention on the Elimination of All Forms of Racial Discrimination; the Convention on the Elimination of Discrimination against Women; and the Convention on the Rights of the Child. Criminalization and victimization of community-based land and environmental rights defenders defy the letter and spirit of Kenya's domestic and international legal obligations to protect Indigenous Peoples such as the Maasai.

\subsubsection{The Sengwer Community versus the State}

According to internet sources, the Sengwer people are an Indigenous community who primarily live in the Embobut Forest in the western highlands of Kenya and in scattered pockets across Trans Nzoia, West Pokot, and Elgeyo-Marakwet counties. The Sengwer people are currently a marginalized community and face significant threats to their identity and ancestral lands. International and human rights organizations, including the United Nations, Amnesty International, and the Kenya Human Rights Commission, recognize the Sengwer as Indigenous Peoples whose claim to the area goes back hundreds of years. The organizations have repeatedly raised concerns about human rights violations against the Sengwer people. ${ }^{41}$

In a series of interviews for this research project with Yator Kiptum, executive director of the community-based Sengwer Indigenous Peoples Programme, Kiptum traced the Sengwer community's land challenges to a period spanning two centuries.

In the 19th century, for instance, the colonial British administration "evicted the Sengwer to enable the establishment of a tea plantation in the area. When Kenya got independence, evictions of the community started in 1978. In the last 10 years, criminalization of the Sengwer has increased." This intensification of unrest for the community arises from efforts by the Kenyan government to evict them from the Embobut Forest, where most of the community lives. At the same time, the forest is an important drainage area-seven rivers (including the Kerio River, one of Kenya's longest) originate from Embobut. Millions of people downstream depend on the water that these rivers provide. 


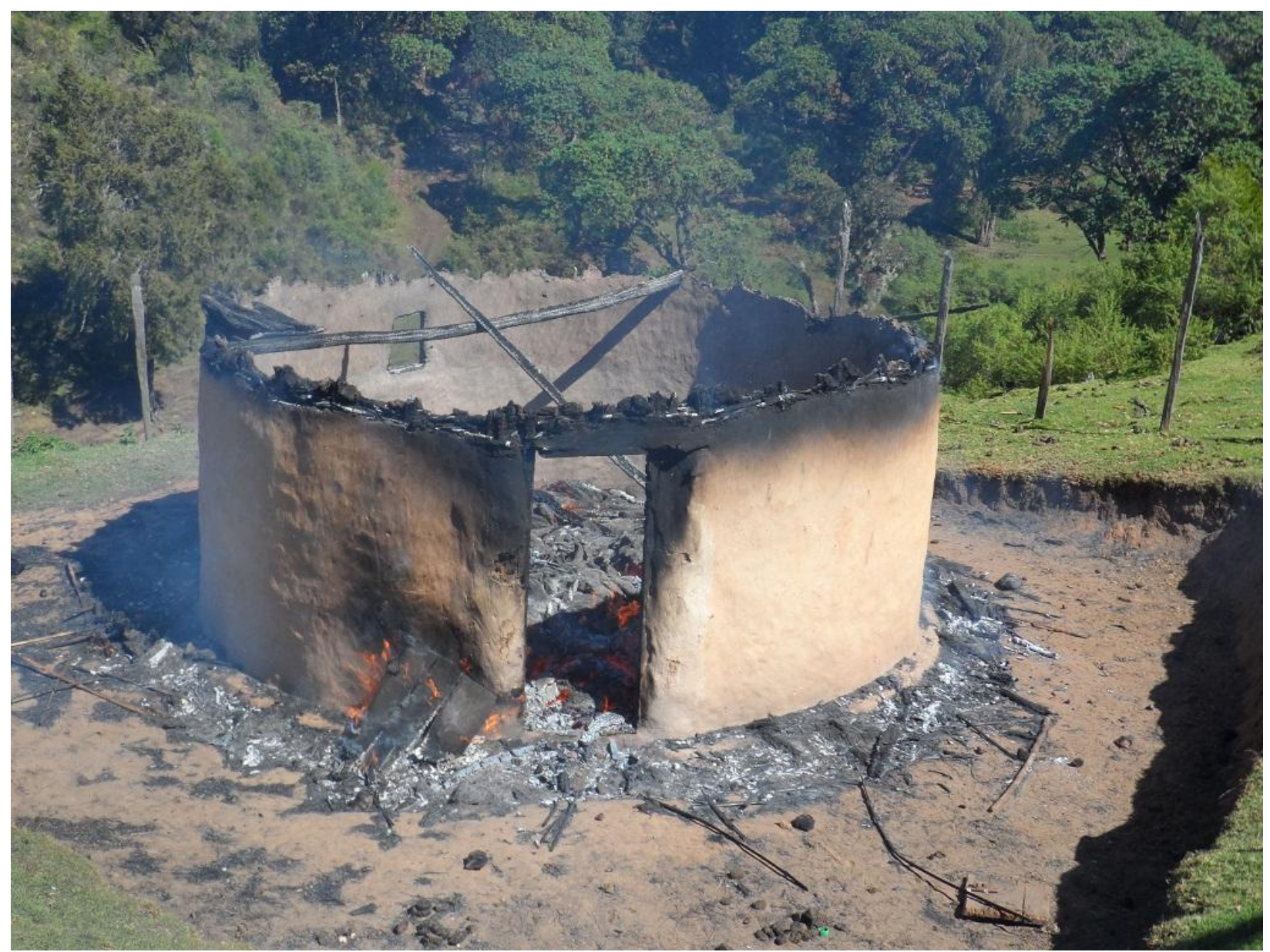

The burned home of a Sengwer community member, following a raid by government security agents a few years ago. (Photo credit: Yator Kiptum) ${ }^{42}$

"The Kenyan administration says that at a time of water scarcity, the Sengwer people are putting the existence of the basin in danger by cutting down trees to create open land for grazing and farming. Its solution: criminalize and evict them. The Kenyan government has labeled the Sengwer people living on their ancestral lands in Embobut forest as 'squatters,' 'internally displaced persons' and 'bandits/criminals' to justify forceful evictions. The government is using various means to forcefully evict the Sengwer," Kiptum has argued elsewhere. ${ }^{43}$

In the interview for this project, Kiptum observed that "When community leaders stand up, they are criminalized and labeled as anti-development. In fact, we are now labeled as a militia by government." This approach by the Kenyan government is not starkly different from that of the Ugandan government (which, as previously noted in the case of Amuru land, has labeled some LERDs in that country as rebels). Community leaders among the Sengwer are equally stigmatized and labeled as treasonous characters. 
"As part of the evictions, our homes have been burnt down, property destroyed, and community members arrested and even killed. On January 16, 2018, Robert Kirotich, a Sengwer tribesman, was shot at and killed by men of the Kenya Forest Service (KFS), the agency that carries out most of the evictions. The forceful evictions have forced members of the community to hide and live in thick forest, in caves, under trees and out in the cold as aliens on their own ancestral lands," Kiptum wrote in 2018 and reaffirmed during an interview conducted for this project. ${ }^{44}$

The Sengwer people, Kiptum contends, "have been subjected to untold suffering, mental torture, discrimination and marginalisation." ${ }^{\prime 4}$

Under the Constitution of Kenya, the following provisions stipulate protection for communities such as the Sengwer:

1. Article 27 (6)-the State shall take legislative and other measures, including affirmative action programmes and policies designed to redress any disadvantage suffered by individuals or groups because of past discrimination.

2. Article 56-The State shall put in place affirmative action programmes designed to ensure that minorities and marginalized groups:

(b) Are provided special opportunities in educational and economic fields

(d) Develop their cultural values, languages and practices. ${ }^{46}$

Kiptum argues, "How will these be achieved when we are being forced into extinction? And, why should we be evicted when Article 63 (2) (d) (ii) recognises that ancestral lands and lands traditionally occupied by hunter-gatherer communities are 'Community lands'? How will the Sengwer of Embobut forest benefit from the Sustainable Development Goals when we are constantly subjected to forceful evictions in our own ancestral lands?"47

In many ways, the case of the Sengwer relates to that of the Maasai people in Kedong Valley, with the government of Kenya as the central source of unrest for these communities and also the lead violator of the rights of LERDs. In both cases, the state is aloof to the concerns of the Indigenous Peoples and focused on pursuing its "development agenda" at all costs, and in so doing, criminalizing land rights defenders among the Sengwer community.

\subsubsection{The Lamu Port-South Sudan-Ethiopia Transport Corridor Project: Big-Ticket Projects and Kenya's LERDs at Crossroads}

An entry point to appreciating the situation of LERDs in Kenya is the Save Lamu initiative and the flak that its actors have had to take from different quarters. In 2009, Lamu Environmental Protection and Conservation "spearheaded an initiative to unite groups and individuals in a campaign to save the 
Lamu Archipelago. Out of this initiative, a coalition of groups came together under the banner Save Lamu. From increasing support from partners and friends, the coalition grew from only 12 local members to now over 40 members consisting of local civil society organisations in Lamu including, but not limited to: environmental groups, development organisations, youth groups, women organisations, welfare groups, and more." ${ }^{\prime 48}$

This, the organization notes, "was made possible through support from Natural Justice, an international NGO based in South Africa, INUKA Kenya Trust, a grassroots movement promoting respect, diversity and self-belief and Development Policy Management Forum (DPMF), a think-tank examining land and resources in Coast Province."49

Since 2013, the initiative notes, "[The] Government of Kenya has laid out plans to develop a 1,050 MW coal-fired electricity plant, the first coal-powered plant in Kenya. The plant's location is along mangrove forests at the mouth of an inlet rich in prawns, crabs and fish. The area is a traditional fishing ground for a number of the more than 3,000 artisanal fisherfolk in Lamu County. Local community members have traditionally used this land for their farms during the planting seasons for generations but lack title deeds for their farms." ${ }^{50}$

To that end, Save Lamu has partnered with other national and international partners under the banner of "deCOALonize" to campaign for alternatives to coal and embracing clean energy in Kenya. Save Lamu has been advocating against the project, citing various social, economic, and environmental concerns. It has carried out several meetings, protests, and workshops to lobby and raise awareness about the impacts of the project.

On May 25, 2018, police arrested two activists during a peaceful protest in Lamu Town, Kenya. The activists, staff of the environmental groups Save Lamu and Lamu Youth Alliance, were protesting the government's decision to proceed with construction of the power plant despite environmental and health concerns. Police held them at the Lamu police station for six hours for participating in an "illegal assembly." They were not charged.

Two days earlier, "police received the required notification of the protest from Lamu Youth Alliance. Under Kenyan law, protesters are allowed to picket, and police have no power to arrest demonstrators in the absence of evidence of a crime. The experience of these activists is symptomatic of the obstacles activists face when opposing the planned power plant and other development projects at Kenya's coast region." ${ }^{51}$

The power plant, according to a 2018 report by Human Rights Watch, is only the latest in a string of planned projects that make up an ambitious, long-standing regional project known as LAPSSET, the Lamu Port-South Sudan-Ethiopia Transport corridor project. Other planned projects include an oil and gas pipeline from Lamu to Turkana, oil and gas drilling that is mainly on Pate Island, and an airport on Manda Island. 
As the Kenyan government moves ahead with financing and implementation of these projects, "communities on the coast have become increasingly concerned about the potential adverse health and environmental impacts as well as inadequate compensation for land acquired by the projects." ${ }^{52}$

Human Rights Watch also stated:

For at least six years, Kenyan and international groups have campaigned both to raise awareness about the environmental and health risks of the various components of LAPSSET and, as in the case of the power plant, (opposing) the project. Activism around the issue made national news when in late 2014 police raided the offices of Save Lamu and summoned key staff for interrogation in Nairobi. Yet, despite harassment and intimidation by authorities, activists have kept up the pressure against LAPSSET and associated projects. In June 2018, environmental activists from across Kenya held a peaceful demonstration in Nairobi against the power plant, attracting international support. In January 2018, the European Union ambassador to Kenya urged the government to drop plans to construct the plant in line with the global drive for clean energy such as wind and solar power that, unlike coal, have low levels of pollution.

In a 2018 report based on research conducted between May and August 2018 by Human Rights Watch and the National Coalition of Human Rights Defenders, the two human rights watchdogs documented "cases of harassment and intimidation against at least 35 environmental activists by police or military and other government officials. The activists include, members of civil society organizations, fishermen and farmers who are generally targeted while engaged in activities such as public interest litigation, holding public meetings and, in a few instances, organizing peaceful demonstrations." ${ }^{53}$ Researchers interviewed 97 people in the Lamu Archipelago, including the affected activists, community leaders, environmentalists, fisherfolk, lawyers representing activists, and police and other government officials, as well witnesses of the abuses against activists.

"The focus of our research was the obstacles faced by activists speaking up about these issues. Police and military officers in Lamu have broken up peaceful protests, banned public meetings by activists, threatened, arrested and prosecuted activists on various charges. In 2016, two activists disappeared; one of them is presumed dead, after being arrested. In at least 15 instances, police accused activists of having links or being sympathetic to Al-Shabab, a Somalia-based militant Islamist group that has carried out numerous attacks in Kenya. Government authorities have responded by denying knowledge of these abuses and casting suspicion on the motivations of the organizations and activists-which they said are influenced more by donor money rather than genuine concern for the environment. Such hostility and dismissive attitude have discouraged activists from reporting abuses and pursuing justice," Human Rights Watch contended.

The Lamu activists, Human Rights Watch argues, represent a test case for Kenya to uphold and protect rights in the context of large-scale development projects. As the LAPSSET project and related projects gain momentum, and as Kenya initiates numerous other development projects across the 
country, "the government should provide space for and protect community engagement—even by those who oppose the projects."

Conclusively, the LAPSSET case is fodder for reflection on big-ticket infrastructure projects in Kenya (as well as in Tanzania and Uganda) and how the state and the funders of these projects deal with violations against LERDs and affected communities. It also presents opportunity for reflection on what strategies LERDs (as individuals, collectives, and organizations) should adopt to challenge criminalization of LERDs in projects of this nature given the chain of actors and stakeholders involved.

\subsubsection{Conclusion on Kenya}

The Kenyan case studies, like those of Tanzania and Uganda, sought to examine how criminalization and victimization of land and environmental rights defenders in that country are manifested. In so doing, the case studies were a fair attempt at tracing the source and nature of conflict between LERDs as communities, individuals, and organizations supporting LERDs on the one hand and the state or commercial business interests on the other. It is evident, as is the case with the two other countries under study, that in spite of commitments captured in Kenya's domestic laws and the international conventions the country has ratified, LERDs continue to live on the edge. It matters less, therefore, what the law provides for in terms of the protections accorded to LERDs and Indigenous Peoples. This mismatch between what is in the law and what obtains in practice is pronounced regarding Indigenous communities such as the Maasai and Sengwer. It is appreciable, however (especially arising from the interviews), that LERDs continue to push back against state and private capital excesses and to defend their land and environmental rights with impressive resilience and tenacity despite the unending victimization and criminalization. As is the case with the other two countries, Kenya's state institutions are either co-opted or hesitant to check the increasing power of companies and state actors that use victimization and criminalization as a means to achieve their interests and subdue communities and LERDs. This situation has bred an atmosphere of impunity.

\subsection{Tanzania}

\subsubsection{Introduction}

The case studies on Tanzania were particularly difficult to conduct given the nature of shrinking civic space in the country, so interviewees agreed to speak only after recommendations from people they trusted. Even then, they did not share a lot of information beyond the realm of what is largely available through literature review. That notwithstanding, however, the consultant made headway and interviewed Ben Baha, Sam Nangaria, Susanna Nordlund, and seven other LERDs, as well as government officials whose request for anonymity has been respected. Most interviewees emphasized the Loliondo case, but efforts were made to capture the situation of other community/Indigenous Peoples' criminalization and victimization in the process of asserting their 
land and environmental rights. As such, the case study of Indigenous Peoples is captured as one to avoid repetition, and the second case study looks at the Maasai-Loliondo debacle.

\subsubsection{The Case of Women (LERDs) in Tanzania's Indigenous Groups}

Tanzania hosts four ethnic groups recognized as Indigenous Peoples: the Akie, the Barabaig, the Hadzabe, and the Maasai. Like other Indigenous Peoples in Kenya and Uganda, these four ethnic groups in Tanzania have repeatedly been subjected to bouts of land rights violations, including land grabbing, and those who challenge these developments (LERDs) suffer even greater human rights infringements. This is partly attributable to the fact that lands of Indigenous Peoples in Tanzania are fodder for wildlife conservation, commercial agriculture, large-scale mining, and luxury tourism facilities. ${ }^{54}$

Cultural Survival, an Indigenous-led NGO, notes that "This has put Indigenous lifestyles and livelihoods at risk as Indigenous groups are evicted from areas with adequate grazing land and water sources. As a result, many Indigenous People are impoverished and food insecure. Land disputes have led to violent confrontations with police, security guards, and farmers, causing injuries, property losses, and deaths." ${ }^{55}$

For this research project, interviews conducted with land and environmental rights defenders from three of the four communities speak to a pattern of systematic labeling of LERDs by government as "anti-development." This categorization is later followed by violence, stigma, criminalization, and victimization. There is, however, a gender dimension to this criminalization of LERDs in Tanzania that deserves a more nuanced analysis. It emanates from the recognition that the lived experiences of women and men in the land rights space are different, and that those differences are actually not innocent but entrenched in structural dynamics of society, politics, and even the "law," where the "law" includes both black and white law as espoused by formal institutions and customary law, as well as law as established by religion (such as sharia law).

The political economy of land and environmental rights defense is not, therefore, a linear affair but one built on the socioeconomic and political context of each society. It is for this reason that the gender aspect of criminalization of LERDs in Tanzania begs more attention and analysis.

One woman from the Barabaig community, speaking on condition of anonymity in an interview for this project, shared that women are considered soft targets by intelligence officers, the army, and police officers involved in crack-down operations in their community. As such, "intimidation is a powerful tool used to break us, to make us the weakest link in the struggle to defend our land and to project us as incapable of standing up to be counted. They also use blackmail through propaganda campaigns against female land rights defenders." 56

The role and place of women in Tanzania regarding land rights deserve mention because this interviewee's sentiments mirror the realities of a society where women's claim to land is steeped in 
patriarchal systems. It follows, therefore, that the cultural resentment toward women's rights to land plays out even in the arena of land and environmental rights. Women come from a place where their contribution to the land rights debate is already determined by premeditated cultural inhibitions. As such, the violence suffered by Tanzanian women who stand up for their land rights, as another interviewee put it, "does not come a surprise." ${ }^{157}$

\section{Researcher Erin Kempster observes:}

Most land in Tanzania is held under customary tenure arrangements with rules and institutions specific to various ethnic groups and geographies. Statutory law, and in some places Islamic law also govern land. A consistent narrative throughout the Tanzanian countryside and across ethnic groups, however, has been women's lack of land rights, or their inability to realize rights where they do exist. Research shows that women lack secure land rights for a number of reasons. For example, about 80 percent of all communities in Tanzania are patrilineal. In patrilineal kinship systems, individuals belong to their father's lineage. They also generally involve the inheritance of property through the male line. ${ }^{58}$

This context is important because it gives us the background to better appreciate the situation of female LERDs in Tanzania's Indigenous communities.

Additionally, in several interviews conducted with LERDs from these communities, the resounding narrative was that the Tanzanian government appears "obsessed with investors" and obsessed with attracting foreign direct investment to East Africa's second-biggest economy. In doing so, the interviewees said, the government disregards the principle of free, prior, informed consent from Indigenous Peoples when dealing in their land with the said investors. Female LERDs who challenge this top-down approach are reminded of their place in society, and when they push the boundaries, they are dealt with using an iron hand. Even when women attempt to deal with this gender-specific dynamic to the land and environmental rights issues affecting their communities using an institutionalized approach-for example, through nonprofit initiatives-those efforts have been thwarted in the past. In today's Tanzania, the situation has only worsened.

To buttress this point, this historical context adds:

The Women's Council of Tanzania (BAWATA) was registered in 1995 and advocated for gender equity and pushed for land reform. BAWATA grew rapidly, incorporating individuals from across the socioeconomic spectrum. It also grew influential and found itself running up against the government's favor. The government soon claimed BAWATA was involved in political activism. In 1996, the government deregistered BAWATA, a move that was heavily criticized by pundits and advocates. The women's movement, however, lost an obvious and likely leader in the struggle for gender equity. ${ }^{59}$

In October 2020, the consultant interviewed two organizations working to advance women's land and environmental rights in Tanzania, but both entities requested that they not be quoted directly, citing the precarious political atmosphere in Tanzania. In effect, whereas in 1996 the Women's Council of Tanzania was deregistered-nipping in the bud an organization committed to advancing 
the cause for Tanzania's women in the land rights arena-in 2020, organizations doing similar work have been subjected to intense censorship while women in Indigenous Peoples communities are isolated and harshly treated.

In one interview with officials from an organization working with pastoral communities in Tanzania, the interviewees shared this response to the question of the nature of criminalization and victimization to which LERDs are subjected: "The government throws around allegations of noncitizenship and basically does stripping of citizenship. [The] Pastoral Women's Council of Tanzania Executive Director has severally been accused, by the government, of being a Kenyan (and not Tanzanian) and in fact her passport seized twice and immigration authorities advised not to let her travel out of the country as she has does not have proper travel documents." ${ }^{160}$

This victimization of female LERDs is cemented by the introduction of draconian laws to curtail operations of NGOs. In 2019, the government amended the NGO law, making it nearly impossible to implement policy advocacy, democratization, human rights, and governance interventions. The laws also introduced burdensome regulations (for example, filing audits on a quarterly basis and seeking government approvals before starting a project), which have led to the closure of many NGOs. An example of an NGO that recently halted its operations due to these draconian regulations is the Tanzania Human Rights Defenders Coalition. Interviewees also cited harassment, unlawful arrest, and prosecution of several human right defenders among the Indigenous communities. Others have been arrested and charged with trumped-up charges. The executive director of the Pastoral Women's Council, for instance, still has a pending charge of treason (ujasusi). She has never been arraigned in court on the charge, "but was arrested for 5 days and severely mistreated and interrogated. She has been warned severally that if she continues with her activism these charges will be revived." ${ }^{61}$

The situation of LERDs in Tanzania is worsened by the fact that, as another interviewee put it:

There is almost complete political capture of all arms of government and most government institutions. The Presidency (which is very authoritarian) is the top most decision making organ in the country. There is a sense that the President (and his officials) is above the law and therefore can give any directives even though unlawful and unconstitutional. The lack of civic freedoms and continued shrinking of civic space has resulted in the media and CSOs [civil society organizations] being forced into self-censorship on matters governance and human rights issues. ${ }^{62}$

And yet, the future looks even bleaker, as another interviewee noted: "The situation will get worse if we don't better organize the community and receive international support (from especially embassies and bilateral agencies such as European Union and USAID [United States Agency for International Development]) to push back on government's plans for eviction of indigenous peoples." ${ }^{\prime 63}$ 
Conclusively, the evidence on the ground in Tanzania speaks to a volatile situation for LERDs, which is worsened by shrinking civic space and government's disregard for the rule of law and for constitutionalism and its obligations under various international civil and political rights instruments. For women, the situation is even further complicated for the reasons previously advanced.

\subsubsection{The Case of the Maasai and the Loliondo Fiasco}

For centuries, the Maasai peoples of East Africa have inhabited parts of what are now Kenya and Tanzania. As DefendDefenders observes, these peoples are known for their "distinctive dress and pervasive pastoralist culture, centered on seminomadic cattle herding. When the Serengeti National Park was gazetted in 1959, many Maasai lost grazing rights in much of the Serengeti and Ngorongoro Crater, and at least 50,000 have since been evicted or displaced, according to some estimates." ${ }^{\prime 64}$

Many settled in areas bordering the park, which has grown in size since its initial boundaries were drawn. On February 3, 2010, a group of Maasai pastoralists filed a claim against Tanzania Breweries Limited and Tanzania Conservation Ltd, the latter of which is a Tanzanian subsidiary of U.S.-based Thomson Safaris. The group alleged that the companies, working with corrupt government officials, "had forcibly evicted them from ancestral land around Loliondo without free, prior, and informed consent, or compensation of any kind." 65

Residents of Mondorosi, Soitsambu, and Sukenya villages alleged that local homes were deliberately set on fire and that human rights defenders had been attacked and arbitrarily detained while accessing areas near the contested land. On October 28, 2015, an Arusha-based High Court ruled against the Maasai, setting a dangerous precedent and paving the way for additional conflict and human rights abuses on neighboring Indigenous land. ${ }^{66}$

These disputed land claims were further compounded by the involvement of the United Arab Emirates-based Otterlo Business Corporation (OBC), which in 1992 was granted big-game hunting and safari rights to a massive stretch of land inhabited by some 50,000 Maasai. Over the next two decades, Tanzanian security agents and private security officials from the company were accused of violently evicting Maasai from these areas and of slaughtering or confiscating cattle in the process.

In July 2016, several Maasai HRDs working on these issues were arrested near Loliondo, as was a lawyer sent to investigate the case after the HRDs in question were held for several days without charges. A year later, in August 2017, “Tanzanian wildlife officials and Tanzanian security forces began torching Maasai homes near Loliondo, and by September more than 5,000 homes had been burned and 20,000 people left homeless, by some estimates." ${ }^{67}$

While the Ministry of Natural Resources and Tourism argued that the evictions were legally acceptable and claims of destruction overstated, 52 HRDs interviewed by DefendDefenders 
described it as "the most violent eviction in living memory, leading to the arbitrary arrests of several HRDs. Many allege that since this time, a pervasive climate of fear has surrounded HRDs attempting to bring these issues to light, including police harassment and confiscation of travel documents. Corruption was cited by nearly all respondents as a major factor contributing to violence in pastoralist communities across northern Tanzania. As one HRD noted, "an investor does not just come in empty-handed. Corruption is the norm of the day." ${ }^{\prime 68}$

In a reversal of tactics, HRDs and civil society organizations (CSOs) dealing with pastoralist issues in northern Tanzania brought the fight not to the battlefield, but to regional courts of law. In October 2017, the combined village councils of Arashi, Kirtalo, Oloirien, and Ololosokwan lodged an official complaint at the East African Court of Justice (EACJ). They demanded that the government of Tanzania formally acknowledge Maasai claims on the disputed land near Loliondo, release HRDs arrested in connection to the case, and cease the harassment of local communities.

However, several HRDs interviewed for this report noted that defendants associated with the case had faced reprisals, notably in the form of arbitrary arrests. In January 2018, the EACJ dismissed a petition on behalf of the government of Tanzania to block the case, affirming the right of village councils to sue the government as legal entities.

In November 2017, OBC's 25-year-old hunting concession was terminated, resulting in the suspension of the director of wildlife and an investigation into alleged corruption between foreign nationals and former and current members of the Ministry of Natural Resources and Tourism. In late September 2018, the EACJ ordered the Tanzanian government to halt the eviction of Maasai pastoralists in Ngorongoro District.

On the basis of input from HRDs and CSOs working on Indigenous human rights issues in northern Tanzania, DefendDefenders observed that several key challenges emerged as HRDs reported being harassed by threatening text messages or phone calls, hostile encounters with police and security forces, arbitrary arrests, spurious charges of incitement or sedition, and a general lack of access to justice. One HRD reported that their passport had been confiscated by authorities after an arrest, barring them from testifying at international human rights mechanisms and advocacy forums. Nearly every HRD interviewed for this report noted that harassment often focused on citizenship, with HRDs accused of being foreign nationals or subversive western-funded agents. Some CSOs were threatened with deregistration or reported being pressured by donors to scale back their advocacy efforts so as to avoid deregistration. In addition to frustrating and intimidating HRDs, these tactics are coupled with a high level of impunity for police, local government officials, or other private sector actors. ${ }^{69}$

Other respondents reported self-censorship practiced by HRDs themselves, usually because of security concerns. A lack of proper networking and solidarity was cited as another challenge for HRDs working with Indigenous communities. Poor communication was cited as a major factor for 
this shortcoming, as pastoralists generally live in remote areas that are not well serviced by the internet and that lack secure telephone connections. These factors further complicate monitoring and reporting efforts. Several organizations also acknowledged a lack of access to regional and international human rights bodies and mechanisms such as the African Commission on Human and Peoples' Rights and the United Nations Human Rights Council. ${ }^{70}$

In 2019, the international nonprofit organization CIVICUS interviewed Joseph Ole Parsambei, executive director of the Tanzania Pastoralist Community Forum (TPCF), about the threats faced by environmental, land, and Indigenous rights activists in Tanzania. TPCF is a nonpartisan, not-for-profit CSO that advances the rights of Tanzania's pastoralist peoples-the Akie, the Barabaig, the Hadzabe, the Maasai, and the Taturu. In that interview, Parsambei pointed out the main challenges faced by land, pastoral, and environmental rights activists and communities in Tanzania. He noted:

The human rights situation in Tanzania is bad, with democracy deteriorating due to the excessive power wielded by private interests that collide with the interest of the majority of Tanzanians. The situation is of regression in both civil and economic rights. It is characterized by the forced displacement of indigenous people from their villages alongside the restriction of the freedoms of association, expression and peaceful assembly-precisely the ones that they would use to resist the violation of their land rights that they are experiencing. Based on my experiences and data collected during fieldwork in rural pastoralist areas, the main challenges faced by Indigenous, land rights and environmental defenders include-but are not limited to-illegal arrest and torture. Many of us have been illegally arrested and detained for prolonged periods without bail or sent to court without any due process guarantees. This has happened on various instances in the Loliondo village over the years, and most recently in the first weeks of 2019. The District Commissioner's office of the Ngorongoro District is mostly responsible for these arrests, since it controls the police and security forces at the district level. ${ }^{71}$

Parsambei shared that malicious prosecution is also used to silence activists so that they don't speak up about the land rights of Indigenous Peoples and other communities. He stated, "Whoever dares to speak about violated rights will face malicious prosecution instigated by powerful corporationsLoliondo, corporations with investments in tourism, notably the Otterlo Business Corporation (OBC), focused on hunting, and Thomson Safaris, which promotes wildlife viewing and photography. They are both behind the torture suffered by activists in Loliondo."172

Many activists, including Ole, have been arrested and detained without accusation, or sued and maliciously prosecuted and sentenced. Some have been killed, such as traditional leader Ole Putaa, a frontline defender of the land rights of the Maasai people, who was arrested by the police and eventually found dead in custody. His was just one prominent example among many cases of activists who have been shot dead or disappeared.

Parsambei noted that "Another tactic used against activism is the de-registration of CSOs. In Loliondo, the activities of the Ngorongoro NGOs Network (NGONET) were suspended by the NGO 
Registry under pressure from $\mathrm{OBC}$ and government officials whose links with investors provide them with private gain."

Loliondo is in Ngorongoro District of the Arusha Region in northern Tanzania; it is the seat of the current district commissioner for Ngorongoro. It is home to about 86,000 pastoralist Maasai, who occupy 98 percent of the area. The area is also close to the Serengeti National Park, which was the original home of the Maasai people before the park was established. In fact, the creation of the park caused about 30,000 pastoralist Maasai to lose their homes.

In that interview, Parsambei further shared, "Whoever speaks up about land grabbing by OBC and Thomson Safaris, or about the land rights of the Maasai people in Loliondo more generally, is subjected to threats. This includes not just local grassroots activists but also others working with CSOs and people in political roles such as councilors-they are all under threat not to speak about this, so access to information in Loliondo has become very difficult."73

In an interview for this research project with Sam Nangaria, a LERD from Tanzania, he noted that activists like him have faced arbitrary arrests and live with continuous threats of arrest from government authorities. Nangaria argued that shrinking civic space in Tanzania complicates the work of LERDs even more because they cannot reach Indigenous communities as effectively as they would have wished to.

The activist identified illegal arrests, prolonged detention, malicious prosecution and sentencing, and torture in custody as the most frequently used tactics to discourage activism, noting that it is difficult to estimate how many activists have disappeared. ${ }^{74}$

In a separate interview for this research paper, Susanna Nordlund observed that sections of the media have been complicit in the criminalization and victimization of Tanzania's LERDs. ${ }^{75}$

Parts of Tanzanian media, Nordlund pointed out, "and notably Manyerere Jackton of the Jamhuri newspaper, have for years conducted a hate and defamation campaign against the Loliondo Maasai and in favour of land alienation. This journalist has published long lists of private individuals in Loliondo that his sources consider to be "Kenyan," fabricated defamatory stories about everyone he suspects of being able to speak up, while painting OBC as philanthropic environmentalists. He has openly boasted about being directly involved in illegal arrests of innocent people. Still, his colleagues seem to view him as a respected veteran journalist, even though he lazily fabricates stories about all kinds of issues." 76

On the other hand, Nordlund shared in her interview that some NGOs had been helpful, and the claim 37 local NGOs, sponsored by foreigners, were stirring up conflict for selfish interests, was an important part of the 'investor friendly' narrative. "There used to be two, not 37, local NGOs doing a good job, but they have been silent these past couple of years. Tanzania Human Rights Defenders 
Coalition have been of great help bringing lawyers when people have been arrested, but they have temporarily suspended their operation after their bank accounts were frozen," Nordlund said. ${ }^{77}$

\subsubsection{Conclusion on Tanzania}

By and large, the observable features of criminalization and victimization of LERDs in Tanzaniawhether those LERDS are acting as individuals, Indigenous Peoples, communities, or nonprofit organizations-have the following hallmarks:

- The situation of Indigenous Peoples in Tanzania is differentiated by their unique history, ways of life, and cultural setup, but in land transactions involving the government and corporate businesses, those unique features of the communities are hardly taken into consideration. Rather, they are used as weak points of entry to grab the people's land and to criminalize those who defend the land and environmental rights of the communities.

- There is an outstanding context of gender-specific dynamics in the struggle for land and environmental rights in Tanzania, which makes the case of women LERDs at organizational, individual, and community levels unique and context-specific, although it is not entirely exclusive to Tanzania.

- As civic space shrinks in Tanzania and the administration of President John Pombe Magufuli suffocates the remaining space for freedom of speech, expression, media, association, and assembly, the plight of LERDs at individual, organizational, and community levels will worsen.

- The state and commercial interests appear to have a convergence of interests that supersede the interests of Indigenous Peoples and their land rights. Defending land and environmental rights in such a context therefore gets complicated even further by what one interviewee called state capture by business interests and corrupt leaders.

- Checks and balances at the level of the judiciary and parliament as counterbalances to executive power and authority appear to be getting blurred in Tanzania. With that, there is less wiggle room for LERDs to challenge actions of the state and be assured of justice.

\subsection{General Observations on Steps Leading to Violence against or Criminalization of LERDs in East Africa}

A pattern can be drawn from a survey of cases of criminalization and victimization of land and environmental rights defenders in East Africa. A part of that pattern involves mapping out and analyzing the nature and source of power, how that power is produced and reproduced, how it leads to criminalization of LERDs, who the main actors are, and what factors lead to these trends. From the case studies, the main actors involved in criminalization of LERDs are governments, their agencies and agents, and both local and multinational large-scale business firms that enjoy significant protection from the state or its agents. In fact, in the case of Uganda, one interviewee (Eron Kiiza, an advocate), alluded to state capture by business interests and actors. With that comes 
private control of state institutions, giving violators of the rights of LERDs a blank check to victimize their victims.

It becomes clear, for instance, that an atmosphere exists in Kenya, Tanzania, and Uganda that breeds violence against and criminalization of land and environmental rights defenders. Key among the gaps and steps leading to this trend include the following:

- State capture. State capture by private business interests renders institutions of the state subservient to private capital and leaves those institutions at the behest of whoever seeks to suppress LERDS. This is pronounced with respect to large infrastructure projects such as LAPSSET in Kenya, the Loliondo case in Tanzania, and the Mubende evictions in Uganda. In all these case studies, it is noticeable that the state is subservient to the interests of businesspeople and investors and that it sacrifices the rights of communities to their land at the altar of "development" and business.

- Corruption. Corruption fuels injudicious actions on the part of state entities in the criminal justice value chain, including police and the courts of law. These actions take the form of trumped-up charges against LERDs and instrumentalization of the law by business and political actors to settle scores with LERDs, as is notable in the Loliondo case in Tanzania. Regina Asinde, who was interviewed for this project, noted that "Corruption must be completely phased out so that perpetrators are held accountable. There is need to overhaul the entire political system in this country (Uganda) which has bred men and women of impunity who abuse their powers to victimize and criminalize land rights defenders in Uganda." 78 Similarly, several interviews with Indigenous Peoples from the Maasai community also led to similar accusations being made against government entities.

- $\quad$ Limited media attention to the plight of LERDs. Whereas LERDs interviewed acknowledged the role of the media in protecting and promoting their rights, they also observed that the media has its own limitations, including (a) lack of presence on the ground in especially rural areas, and (b) intimidation or corruption of some journalists by government, businesspeople, and whoever seeks to suppress LERDs. The role the media has played has ranged from "incompetent to downright criminal," ${ }^{79}$ according to Susanna Nordlund, who has worked with Tanzanian media in her activism related to the Loliondo case.

In response to questions sent to her for this project, Nordlund said: "There was some serious reporting in the early 1990s about a corruption scandal in which OBC got the right to hunt in Loliondo, but since then there hasn't been any Tanzanian investigative journalism about Loliondo at all. I suppose the issues aren't interesting enough to justify the risks. A couple of international journalists have been detained and asked to leave the district, and one was murdered after leaving. Some international media have been helpful, but more interested in using Loliondo to illustrate their narrative about Indigenous rights, or against trophy hunting, than keeping to facts. Parts of Tanzanian media, and notably Manyerere Jackton in the Jamhuri newspaper, have for years conducted a hate and defamation campaign against the Loliondo 
Maasai and in favour of land alienation. This journalist has published long lists of private individuals in Loliondo that his sources consider to be "Kenyan" [and] fabricated defamatory stories about everyone he suspects of being able to speak up, while painting OBC as philanthropic environmentalists. He has openly boasted about being directly involved in illegal arrests of innocent people. Still, his colleagues seem to view him as a respected veteran journalist, even though he lazily fabricates stories about all kinds of issues. Similarly, the media was faulted in the case of Mubende land evictions in Uganda for being rather too meek, and other journalists accused of being bribed into silence. ${ }^{80}$

On a positive note, in the case of Zoka Forest, the activists interviewed praised the media for bringing to the fore the issues the community would ordinarily have failed to give prominence on their own. Either way, the pivotal role of the press in protection of LERDs cannot be overemphasized in all the three countries. ${ }^{81}$

- Shrinking civic space and waning civil society fraternity on issues of land and the environment. Sam Mucunguzi, the coordinator of Citizens' Concern Africa, noted in an interview: "There is censorship of NGOs; state agents can come to your office and grab everything, like what happened at Action Aid International Uganda office in 2017. Indeed, some NGOs have backed down so they don't know what is going on and they think they should go slow on land issues."

In the case of Tanzania, Nordlund notes that "Some NGOs have been most helpful, and an important part of the 'investor-friendly' narrative is to claim that there are '37' local NGOs, sponsored by foreigners, that are stirring up conflict for selfish interests. There used to be two, not 37, local NGOs doing a good job, but they have been silent these past couple of years. Tanzania Human Rights Defenders Coalition have been of great help, bringing lawyers when people have been arrested, but they have temporarily suspended their operations after their bank accounts were frozen."

Although there have been incidents in which the media and CSOs have spoken out against the criminalization and victimization of land defenders, most of the time these stories are not captured and go undocumented. The ones that are documented are not followed up on. Some media companies and CSOs are afraid to speak objectively against the politically connected perpetrators (which is most of the time) and so will usually choose to dissociate themselves from these stories. Sometimes, when the media and CSOs cover the stories, they will downplay the repression or even injustice to avoid stepping on the toes of the perpetrators. ${ }^{82}$ Because of this vacuum, it goes without saying that violators of LERDs act with confidence and the unwritten assurance that they can get away with their actions, as seen in all the studied cases.

- Weak court system. The courts of law play a pivotal role in the resolution of disputes in society, and in the case of LERDs they are often the last line of defense available for communities threatened by powerful forces. However, there are challenges of speed and access to courts in 
East Africa for several LERDs interviewed, as well as costs of litigation. In an interview, Mucunguzi shared, "One of the things that have actually pushed human rights defenders into silence is the court system because over time we have tried our best to go to court but the courts are not effective and make the entire process worse. Also, they are too expensive, especially for the affected people. The Land Act had established land tribunals which were to hear cases without relying on the traditional court system that takes long and to make sure that people get justice, but in Uganda all that remains on paper." 83 This point is applicable to the case of Mubende in Uganda and the Loliondo case in Tanzania. It is also applicable to the case of the Masaai people, where disputes between communities and the state or commercial entities have ended up in court and the communities remained without protection, thanks in part to the snaillike speed of the court system. To solve this challenge, Nordlund proposed that LERDs and Indigenous Peoples in the region consider regional courts (such as the East African Court of Justice, where four villages have sued the government of Tanzania).

- Pressure on land resources. Some LERDs interviewed contend that the growing agrarian crises-fueled by the failure of land reform measures, corporate takeover of lands, privatization of basic services, increase in development-induced displacement, and usurpation of agricultural land of small farmers-are all contributing to land and environmental rights becoming a central social justice and human rights issue in East Africa. This, Regina Asinde noted, is compounded by political interference, corruption, and impunity.

In several instances, "people with good political connections have encroached on wetlands and water catchment systems with no reprimand from law enforcers. During COVID-19, a number of politically connected individuals forced whole communities off their land in areas like Kiryandongo. Land and environmental rights defenders who spoke up and protested these rights violations were arrested, intimidated, and threatened. Homes of communities that resisted the land injustice were burned down, their property destroyed, and sometimes they were beaten and seriously injured. In each of the cases, the police force, UWA, and UPDF were the enforcing agencies used to repress the voices of LERDs." ${ }^{84}$ This point applies to all the cases under study as captured in each countryspecific case study.

- Delegitimization of the broader rights agenda. Delegitimization of the broader rights agenda has contributed to false narratives that paint Indigenous Peoples as impediments to progress, rolling back some of the most significant gains in collective rights in several countries across the globe. It has also contributed to the uptick in the risks of violence and criminalization for Indigenous Peoples, Afro-descendants, local community members, and women leaders on the ground.

Interviewees noted that the situation will escalate and worsen as more extractives are discovered and as governments push for more agrarian investors to engage in multibillion-shilling commercialized farming. More and more foreign governments, Asinde argued, "are looking to engage in multibillion food production on the African continent to feed their populations [at] home. 
This means that more small household farmers will lose their land and environmental degradation will be on the rise. ${ }^{185}$ As captured in the case of Loliondo, the Masaai community, and the Amuru case in Uganda, governments are shaping the narrative and depicting LERDs as antagonistic about development. That way, justification is made for their suppression.

- Weakened role of parliament. Several times, it was noted across the three countries during interviews, parliaments have responded positively when communities have petitioned them regarding land and environmental rights violations. Unfortunately, those interventions from the parliaments have not been effective in the protection of the human rights defenders because the security agencies or individuals perpetrating the injustices have ignored parliaments and gone ahead to victimize LERDs. The courts are in most cases complicit in this chain link of injustice. Rarely have defenders received justice from the courts, "since most perpetrators use court orders to victimize communities and defenders," an interviewee from Tanzania noted. ${ }^{86}$ Sticking to Tanzania, this point particularly resonates with the case studies captured in this report.

There is a need to have judicial and legal systems that are independent and free from political interference and corruption. As long as these entities continue to be riddled with corruption and to pander to the desires of politically well-connected individuals, there is not much hope for justice from their quarters. ${ }^{87}$

Asinde noted in an interview:

We have seen communities rendered landless because of the extractives industry which is slowly gaining ground in Uganda. The discovery of oil in Uganda, phosphates in Tororo, gold in Busia, have contributed to the repression and oppression of communities and HRDs who speak up against the rights violations in these areas. As more dams are constructed and more foreign "investors" engage in multibillion agricultural production hence usurping land from small household farmers, land and environmental rights violations rise steadily. More forests are cut down to cater [to] the greed of the multibillion agrarian manufacturers such as the sugar industry. Settlement of refugees has also been a major contributor to this problem in Uganda. The government has grabbed massive chunks of land from neighboring communities in Kiryadongo and Kyangwali to expand the refugee resettlement camps. In some areas like Kyangwali, communities have been forced into resettlement camps after their land was grabbed by the government, and members of the community who challenge these developments are stigmatized and victimized by the state. ${ }^{88}$

As these and earlier observations show, the story of criminalization of LERDs in East Africa is one of missing links at different levels: governments, civil society, private companies, and Indigenous Peoples and communities. Any break in the chain of stakeholders charged with protection of LERDs is bound to result in more criminalization of LERDs in the region. 


\subsection{Existing Strategies and Resources to Address the Criminalization of LERDs in East Africa, and Organizations Working on the Issue at the Local, National, and Regional Levels}

EarthRights International notes that land and environmental rights activists are facing a global wave of repression and violence linked to land disputes, natural resources, and climate change. It notes that 207 killings of land and environment defenders were documented in 2017, the worst year on record. In response to this violence and to mark the 20th anniversary of the UN Declaration on Human Rights Defenders, EarthRights International launched a new action plan and interactive web platform titled "Fighting Back: A Global Protection Strategy for EarthRights Defenders." "Fighting Back" lays out a road map to protect the rights of earth rights defenders so that they can continue their important work of protecting our planet.

The framework adopts a four-pronged approach: address immediate threats to earth rights defenders, including to keep them safe (protect); address the structural issues that cause threats to earth rights defenders, including to prevent the shrinking of space for civil society and Indigenous rights (prevent); [shine] a light to reveal collusion and corruption and to expose all those who perpetrate abuse (reveal); and obtain justice for victims by holding the perpetrators accountable (redress). ${ }^{89}$

The global protection strategy by EarthRights International contains concrete actions that will help reduce the number and severity of attacks against earth rights defenders. The strategy includes

actions to fight projects that extract and exploit, fight corruption, challenge donor policies that harm defenders, strengthen the skills of and resources available to earth rights defenders, and include options for use of the legal system. It is our hope that by outlining our vision and strategy that civil society-including both national and international NGOs_can act in a coordinated and strategic way, and with our collective efforts scaled up, to be more effective in working to reduce threats and attacks against earth rights defenders. We also hope that the strategy acts as a guide for funders, and a resource for communities, governments, international institutions, and others who want to support the work of earth rights defenders. The strategy also references the responsibilities of governments, companies, and the international finance institutions (IFI). ${ }^{90}$

In terms of strategies, it is apparent that there exists some reasonable and actually commendable peer support within the NGO network to stand with LERDS facing criminalization and victimization in the region. In Uganda, for instance, a small pressure group like Friends of Zoka was able to get support from NGOs such as AJWS, Care International, Chapter Four, Human Rights Center Uganda, IUCN, and National Coalition of Human Rights Defenders - Uganda. Such peer support is instrumental in giving pressure groups and Indigenous communities like those in Uganda's Zoka Forest the requisite morale and capacity building backup they desperately need to keep "walking the talk." At the top, institutions such as the European Union are helpful by way of recognizing human rights defenders and giving them moral support through the awards to LERDs. Different embassies 
and high commissions also support individuals and organizations both covertly and overtly in the different countries.

In Kenya, NGOs such as the Ogiek Peoples' Development Program (OPDP) support grassroots efforts to defend LERDs, another form of peer support. The OPDP is a Kenyan NGO working to help fight for the rights of the Ogiek community. The organization, which began in 1999, consists of "Ogiek elders, opinion leaders, farmers and professionals" who "work to fight against oppressive laws, policies and deep seated discrimination and exclusion." ${ }^{11}$ The organization focuses on land and natural resources rights, strengthening good governance and institutional capacity, and building community identity and active participation, as well as increasing gender and youth empowerment.

This organization, like a handful of others, has benefited from the support of the Kenya Community Development Foundation (KCDF). According to its website, KCDF is a Kenyan development grantmaking organization, founded and registered in 1997 as a public foundation. It supports communities' efforts to initiate and drive their development agenda by harnessing and growing their resources as well as securing their basic rights and services from duty bearers. KCDF works with poor, marginalized, and disadvantaged communities as its primary target group and looks to support them in uplifting themselves from their situation through their own efforts. A secondary target group involves organized communities that are looking to uplift themselves in a sustainable manner through asset building. KCDF thus invests significant resources to build, strengthen, and sustain the core capacities of these communities by developing thoughtful, long-term collaborations with other actors such as governments, nonprofit organizations, the business sector, and individuals to achieve social justice. ${ }^{92}$

DefendDefenders is the East and Horn of Africa Human Rights Defenders Project. According to its website, the organization seeks to "strengthen the work of human rights defenders (HRDs) throughout the region by reducing their vulnerability to the risk of persecution and by enhancing their capacity to effectively defend human rights." DefendDefenders works in Burundi, Djibouti, Eritrea, Ethiopia, Kenya, Rwanda, Somalia (together with Somaliland), South Sudan, Sudan, Tanzania, and Uganda. ${ }^{93}$

DefendDefenders serves as the Secretariat of East and Horn of Africa Human Rights Defenders Network, representing more than 78 members (that is, HRDs and their organizations). The Network "envisions a region in which the human rights of every citizen as stipulated by the Universal Declaration of Human Rights (UDHR) are respected and upheld. Its mission is to maximize the protection of HRDs working in the sub-region and to enhance the awareness of human rights work through linkages with national, regional and international like-minded entities." ${ }^{\prime 94}$

DefendDefenders was established as a regional NGO based in Uganda in 2005, following extensive field research in the region, which identified the most pressing and unmet needs of human rights 
defenders in order to seek to overcome some of the resulting challenges. The critical areas that were identified as needing to be addressed included the following:

1. Insufficient collaboration amongst human-rights organizations, especially those working in neighboring countries;

2. Resource constraints (notably material) which greatly undermine the effectiveness of the work carried out by human rights defenders;

3. Knowledge gaps, in particular regarding international human rights instruments and mechanisms as well as crisis management;

4. The need at times to supplement the efforts of local and national human-rights defenders by the wider international community, especially when attacks on intra-national HRDs are involved, hence the need for systematic protocols for such support. ${ }^{95}$

- Defending Land and Environmental Defenders Coalition (DD Coalition): The DD Coalition works to build protection skills among defenders, strengthen government and business safeguards for defenders, and protect civil society actors who are addressing root causes of threats and attacks on defenders.

Land and environmental defenders, according to the DD Coalition website, "face growing threats around the world. Over the last three years, approximately 200 individuals defending the right to a healthy environment and territory have been killed each year. Defenders continue to be criminalized and subjected to violent attacks-including murder-within a shrinking operating space for civil society." To that end, the Coalition works to build protection skills among defenders, to strengthen government and business safeguards for defenders, and to protect civil society actors who are addressing root causes of threats and attacks on defenders. They do those things by sharing experiences; in so doing, they minimize duplication and maximize impact.

According to the DD Coalition website:

Within the Coalition some organizations have extensive experience responding to acute attacks and helping individuals and organizations build resilience. Others have experience advocating with businesses and governments to protect defenders. We are learning about what resources already exist to support defenders, and sharing knowledge about how to access those resources. We are supporting members' initiatives to improve safeguards and protections mechanisms, and so amplify their impact. The Coalition aims to:

-Share learning and build protection skills for defenders around the world;

-Launch a web portal with support resources for defenders at the international level and in four pilot countries;

-Support member initiatives to collect data on criminalization, threats and attacks against defenders, in addition to data on killings already collected; 
-Promote ratification of the Escazu Agreement in Latin America, which includes and requires strong protections for defenders;

-Work with diplomatic missions to improve protections for defenders and emergency support;

-Work with businesses to integrate strong protections for defenders into policies and practices;

-Analyze existing commitments and policies by business and governments to protect defenders and implementation of those policies and commitments;

-Facilitate broad and rapid response to emergencies by providing a forum for individuals and organizations to reach out to intermediary support organizations;

The DD Coalition Steering Committee is composed of the following members:

Action for Large-scale Land Acquisition Transparency

African Defenders

All Eyes on the Amazon

Amazon Watch

Asian Forum for Human Rights and Development

Center for Development Alternatives (CEALDES)

Center for Justice Governance and Environmental Action (CJGEA)

Community Agroecology Network

Consortium for Agrarian Reform

DefendDefenders

Freedom House

Green Advocates

Friends of Lake Turkana (Kenya)

Humanist Institute for Cooperation with Developing Countries

Latin America Working Group (LAWG)

Natural Justice

Not One More

Pan-African Institute for Research, Training, and Action for Citizenship, Consumption, and Development in Africa (CICODEV)

Pastoral Women's Council (PWC) in Tanzania

Southern Africa Human Rights Defenders Network

Washington Office on Latin America (WOLA)

Zimbabwe Environmental Law Association (ZELA)

International members of the Steering Committee include: 
350.org

AIDA

American Bar Association (ABA)

Amnesty International USA

Article 19

Business \& Human Rights Resource Centre

Center for Human Rights and Environment

Center for International Environmental Law (CIEL)

Civicus

Coalition for Human Rights in Development

Digital Defenders Partnership

EarthRights International (ERI)

Environmental Defender Law Center (EDLC)

Environmental Investigation Agency (EIA)

Environmental Law Alliance Worldwide (ELAW)

Forest Peoples Programme

Front Line Defenders

Gender and Environmental Resource Center

Global Greengrants Fund

Global Witness

Goldman Environmental Prize

Hivos

Huairou Commission

Human Rights Watch

The ICCA Consortium

International Land Coalition (ILC)

International Rivers

International Union for Conservation of Nature (IUCN)

International Work Group for Indigenous Affairs (IWGIA)

International Land Coalition (ILC)

Land is Life

Namati

Oxfam Novib

Open Society Initiative for Eastern Africa (OSIEA)

Peace Brigades International (PBI) 
Publish What You Pay (PWYP)

Rights and Resources Initiative (RRI)

Stockholm Resilience Centre

Swedish Society for Nature Conservation (SSNC)

Swedwatch

Transparency International

Trócaire

Universal Rights Group (URG)

Vuka! Coalition for Civic Action

Water Witness International (WWI)

Waterkeeper Alliance

We Effect

World Resources Institute (WRI)

\subsection{Main Findings (Conclusion) and Recommendations}

\subsection{Main Findings}

1. Criminalization of land and environmental rights defenders in East Africa involves two main layers of power: (a) those wielding or protected by the power of the state, and (b) corporate/business power, usually multinational projects. Infrastructure projects, as well as conservation efforts by governments in the region, are also fueling land conflicts in the region, resulting in criminalization of LERDs who raise questions.

2. There is a pattern of instrumentalization of the law and weaponizing justice and law and order sector institutions in Kenya, Tanzania, and Uganda to crack down on LERDs. This includes private commercial interests that have those institutions at their disposal.

3. The collective rights of ethnic minorities and Indigenous Peoples in the three countries are constantly under attack from both the state and business interests and parliaments. Judiciaries in the three countries appear incapable of defending them, leaving most of the defense of these peoples to civil society organizations.

4. As civic space and the rule of law shrinks and East Africa registers signs of democratic rollbackespecially in Tanzania and Uganda-impunity has become commonplace with respect to the rights of LERDs and community-based land rights defenders as well as nonprofit organizations working in the land rights and environmental rights space.

5. Although state organs and institutions (especially the judiciary) are active and vibrant in mediating between aggrieved LERDs and the state/business interests, they appear to be generally nonresponsive to the urgent needs of LERDs in distress, considering the snail-slow pace at which the wheels of justice roll even on life-and-death matters. 
6. Whereas there exist strategies and civil society efforts to support LERDs in the region, many human rights defenders find themselves helpless—with limited resources, if any-and often time lacking capacity to sustain efforts geared at asserting their rights. This situation prevails despite the fact that the forces they are fighting are usually monied and have plenty of human and technical resources at their disposal.

7. As land-based investments in the region increase and pressure on land resources rises, due in part to population growth and urbanization in East Africa, tensions will keep rising between states/business interests and communities/Indigenous Peoples. The challenges ahead are, however, not matched with equal growth in resources for LERDs. This mismatch will increase pressure on the few LERDs and organizations in that space and make them even thinner on the ground.

8. Affected communities/Indigenous Peoples and individual LERDs whose rights are violated are hardly compensated even when they win in the courts of law. There is also limited legal support available to these LERDs, essentially leaving many of them to fight on their own.

\subsection{Recommendations}

This report associates itself with the school of thought advanced by Global Witness to the effect that land and environmental rights defenders will be able to carry out their activism safely only when states, companies, and investors take action to tackle the root causes of conflict, safeguard defender rights, and ensure accountability when attacks occur. ${ }^{96}$ Accordingly, a three-pronged approach is recommended. First, governments in East Africa, civil society organizations, and companies should clearly identify and address the root causes of tensions between LERDs, communities, and Indigenous Peoples on the one hand and governments/business interests on the other. This is largely dependent on the facts and circumstances of each case. Second, all stakeholders' efforts should be geared toward protection of the rights of LERDs. Third, governments must ensure that accountability mechanisms work and deliver justice when violations of LERDs' human rights occur. In more specific terms, the following recommendations are made:

- Governments in East Africa should resolve outstanding land claims and formally secure the land rights of endangered communities and Indigenous Peoples.

- Governments should address land inequality, including with regard to gender and ethnic minorities in line with the constitutions of the respective countries as well as international legal instruments and conventions.

- Governments and civil society should ensure that all businesses comply with the concept of free, prior, and informed consent of Indigenous communities at all phases of the project cycle or operation.

- Governments and civil society should insist on environmental and social impact assessments of proposed business operations in line with the relevant laws of the countries concerned and the results of any assessment made public and used to mitigate against adverse impacts that communities experience. 
To protect rights of LERDs and Indigenous Peoples/communities, governments should do the following:

- Legitimize the role of LERDS and publicly condemn any threats against them, with specific attention to gender-based violence and attacks.

- Ensure that national policies safeguard the rights of defenders to free assembly and speech, as well as potential recourse to civil disobedience.

- Provide effective accountability mechanisms at every level that deliver tangible results in defenders' lives, in line with international law and practice of civilized nations.

- Bring to justice those responsible for ordering or carrying out any threat or attack against a land or environmental defender.

- Prevent, investigate, punish, and redress corruption, human rights abuses, and environmental damage through effective policies, legislation, regulations, and reparations, including holding companies and investors to account on their obligations when operating projects or sourcing land-based goods, both at home and abroad.

- Make foreign aid and investment in projects conditional on whether specific measures for the security of land and environmental defenders are in place. Global Witness also recommends that companies should cooperate with, assist, and in no way hinder investigations by state authorities into instances of attacks on land and environment defenders ${ }^{97}$

- Provide for or cooperate in remedies and reparations for defenders, organizations, and communities affected by threats and attacks

- Take immediate action to suspend business projects and relationships with business partners in situations in which defenders have been threatened, until robust measures are taken to protect those at risk and prevent further harm ${ }^{98}$

\section{Recommended Reading}

Avocats Sans Frontiéres. 2014. Human Rights Implications of Extractive Industry Activities in Uganda: A Study of the Mineral Sector in Karamoja and the Oil Refinery in Bunyoro. Avocats Sans Frontiéres, Kampala, Uganda. Available at: https://asf.be/wpcontent/uploads/2014/09/ASF_UG_ExtractiveSectorHRImplications.pdf.

Mutambukah, Benjamin B. 2020. The Benet's Struggle to Secure Their Land. Accessed November 1, 2020. Alliance for Food Sovereignty in Africa, Kampala, Uganda. Available at: https://afsafrica.org/wpcontent/uploads/2019/04/the-benets-struggle-to-secure-a4-1.pdf.

Cultural Survival. 2015. Observations on the State of Indigenous Human Rights in the United Republic of Tanzania in Light of the UN Declaration on the Rights of Indigenous Peoples. Prepared for United Nations Human Rights Council, 2nd Cycle of Universal Periodic Review of Tanzania. Cultural Survival, Cambridge, MA. 
DefendDefenders. 2018. To Them, We're Not Even Human: Marginalised Human Rights Defenders in Uganda, Kenya, and Tanzania. Accessed November 11, 2020. Available at: https://defenddefenders.org/wpcontent/uploads/2018/12/FINAL-REPORT pdf-3-1.pdf.

ESCR-Net. 2020. Kenya: Stop the Judicial Harassment of Land Rights Defenders. Accessed November 21, 2020. Available at https://www.escr-net.org/news/2020/kenya-stop-judicial-harassment-land-rightsdefenders.

Kempster, Erin. 2019. Brief: Gender and Land Rights Debate in Tanzania. Accessed November 20, 2020. Available at: http://www.focusonland.com/fola/en/countries/brief-gender-and-land-rights-debate-intanzania/.

Nelson, Fred, Emmanuel Sulle, and Edward Lekaita. 2012. Land Grabbing and Political Transformation in Tanzania. Paper presented at the Global Land Grabbing II Conference, Ithaca, NY, October 17-19.

Ngoitiko, Maanda and Fred Nelson. .2013. “What Africa Can Learn from Tanzania's Remarkable Masai Lands Rights Victory." Guardian, October 8, 2013. Available at: https://www.theguardian.com/globaldevelopment/poverty-matters/2013/oct/08/africa-tanzania-masai-land-rights-victory.

National Land Use Planning Commission (NLUPC). 2011. Guidelines for Participatory Village Land Use Planning, Administration and Management in Tanzania, 3rd ed., Dar es Salaam, Tanzania: NLUPC.

New Vision. 2017. "Amuru Women Strip to Block Land Survey." Accessed November 21, 2020. Available at: https://ugandansatheart.blogspot.com/2017/08/uah-amuru-women-strip-to-block-land.html

Freedom House. 2016. "Kenya: Assessment of Civil Liberties, Political Rights," news release. September $28,2016$. Available at: https://freedomhouse.org/article/kenya-assessment-civil-liberties-political-rights.

Kameri-Mbote, Patricia. 2009. “The Land Question in Kenya: Legal and Ethical Dimensions.” Nairobi, Kenya, Strathmore University and Law Africa, Nairobi.

Mbazira, Christopher and Teddy Namatovu. 2018. Civic space and human rights advocacy in the extractive industry in Uganda: Implications of the 2016 Non-Governmental Organisations Act for oil and gas civil society organisations. African Human Rights Law Journal 18 (1): 75-99.

The Legal and Human Rights Centre and Zanzibar Legal Service Centre. 2016. Tanzania Civil and Political Rights Perceptions Index 2016. https://www.humanrights.or.tz/assets/attachments/1504338107.pdf

Kipobota, Clarence. 2013. Report on the State of Pastoralists' Human Rights in Tanzania: Survey of Ten Districts in Tanzania Mainland 2010/2011. Parakuiyo Pastoralists Indigenous Community Development Organization. Available at: https://www.iwgia.org/images/publications/0626_Human_Rights_Book_FINAL.pdf.

Report of the Special Rapporteur on the Situation of Human Rights Defenders, Presented to the United Nations General Assembly on August 3, 2016, para.7. 2016. Available at: https://undocs.org/A/71/281. 
United Nations Human Rights Office of the High Commissioner. Declaration on Human Rights Defenders. Accessed August 11, 2020. Available at: https://www.ohchr.org/en/issues/srhrdefenders/pages/declaration.aspx.

Human Rights Watch. 2018. "They Just Want to Silence Us": Abuses Against Environmental Activists at Kenya's Coast Region. Available at: https://www.hrw.org/report/2018/12/17/they-just-want-silence-us/abusesagainst-environmental-activists-kenyas-coast.

Global Witness. 2020. Defending Tomorrow: The Climate Crisis and Threats against Land and Environmental Defenders. Global Witness, London. Available at: https://www.globalwitness.org/en/campaigns/environmental-activists/defending-tomorrow/.

\section{International Legal Instruments and Conventions}

African Charter on Human and Peoples' Rights, 1981

African Charter on the Rights and Welfare of the Child, $f 1990$

Beijing Declaration and Platform for Action, 1995

Convention on Biological Diversity, 1992

Convention for the Safeguarding of the Intangible Cultural Heritage, 2003

Covenant on Economic, Social and Cultural Rights, 1966

Covenant on Civil and Political Rights, 1966

Convention on the Rights of the Child, 1989

Convention on the Elimination of All Forms of Discrimination against Women, 1979

Indigenous and Tribal Peoples Convention, 1989

Convention on the Elimination of All Forms of Racial Discrimination, 1965

Convention on the Protection and Promotion of the Diversity of Cultural Expressions, 2005

Convention Concerning the Protection of the World Cultural and Natural Heritage, 1972

Convention against Torture and Other Cruel, Inhuman or Degrading Treatment or Punishment, 1984

Convention on the Protection of the Rights of All Migrant Workers and Members of Their Families, 1990 
1994 International Conference on Population and Development

Protocol to the African Charter on Human and Peoples' Rights on the Rights of Women in Africa, 2000

UNEP Malmö Ministerial Declaration of 2000

Universal Declaration of Human Rights, 1948

United Nations Declaration on the Rights of Indigenous Peoples, 2007

United Nations Declaration on the Rights of Persons belonging to National or Ethnic,

Religious and Linguistic Minorities, 1993

Universal Declaration on Cultural Diversity, 2001 


\section{Annex 1: Questionnaire Used during the Interviews}

1. New threats are emerging as some governments attempt to roll back the hard-won gains of the rights recognition agenda, often in the name of "development." This manifests in various forms including legal or judicial changes, institutional shifts, or intensified direct violence and criminalization against local peoples asserting their rights over lands, forests, and natural resources. In respect of the above, kindly share the experience in Tanzania from where you sit as a land and environmental rights defender.

2. The delegitimization of the broader rights agenda has contributed to false narratives painting local peoples as impediments to progress, rolling back some of the most significant gains in collective rights in several countries across the globe. It has also contributed to the uptick in the risks of violence and criminalization for Indigenous, Afro-descendants, local community, and women leaders on the ground. Do you get the sense that this is the case in Tanzania/Uganda/Kenya in terms of how the narrative is framed?

3. While Asia and Latin America have more cases of criminalization of land rights defenders, incidents are steadily increasing in Africa, especially in the Eastern part of the continent. This is largely due to major land-based investments. From 2017 to 2019, several cases of criminalization of land rights defenders have been signaled in Africa, particularly in Uganda, Tanzania, Kenya. What in your view is causing this?

4. How does victimization and criminalization of land and environmental rights defenders manifest in your country?

5. Kindly share your personal experience or the lived experience of colleagues in the sector.

6. Do you get the sense that the courts, parliament are helping in the protection of land and environmental rights defenders in your country? Where are the gaps and what proposals do you have for improvement?

7. How would you assess the role that the media is playing or not playing as well as civil society organisations in ensuring land and environmental rights defenders are not criminalized or victimized?

8. What are your projections for the future in the context of land and environmental rights issues in the region? Will the situation get worse or better? Why?

9. Which particular cases (3-5) stand out for you in the recent past (two or three years) in terms of criminalization and victimization of land and environmental rights defenders?

10. What needs to be done to address the criminalization and victimization of land and environmental rights defenders in the country? 


\section{Endnotes}

1 Global Witness. 2020. Defending Tomorrow: The Climate Crisis and Threats against Land and Environmental Defenders. Global Witness. Available at: https://www.globalwitness.org/en/campaigns/environmentalactivists/defending-tomorrow/.

2 Rights and Resources Initiative (RRI). 2021 (forthcoming). Collection, Systematization and Analysis of Patterns of Criminalization and Violation of the Rights of Indigenous Peoples, Afro-descendants and Local Communities in the Period 2017-2019, Linked to the Interests of Extractive Industries and Infrastructure Development with a Focus on Brazil, Colombia, Guatemala, Honduras, Mexico, and Peru. Draft report cited with permission. Washington: Rights and Resources Initiative: p. 4.

${ }^{3}$ RRI 2021: p.7.

${ }^{4}$ Article 1 of the United Nations Declaration on the Rights of Indigenous Peoples of 2007 states that "Indigenous peoples have the right to the full enjoyment, as a collective or as individuals, of all human rights and fundamental freedoms as recognized in the Charter of the United Nations, the Universal Declaration of Human Rights and international human rights law."

5 United Nations Declaration on the Rights of Indigenous Peoples of 2007, Article 1.

${ }^{6}$ RRI 2021: p.37.

7 RRI 2021: p.37

8 National Coalition of Human Rights Defenders - Uganda. 2020. 5.

${ }^{9}$ Civicus. 2017. Land Rights and Environmental Activism: A case study from Kenya. Accessed December 12, 2020. Johannesburg: Civicus: p.1. Available at: https://www.civicus.org/documents/reports-andpublications/SOCS/2017/essays/land-rights-and-environmental-activism-a-case-study-from-kenya.pdf.

10 Human Rights Watch. 2018. They Just Want to Silence Us": Abuses against Environmental Activists at Kenya's Coast Region. Available at: https://www.hrw.org/report/2018/12/17/they-just-want-silence-us/abuses-againstenvironmental-activists-kenyas-coast.

11 DefendDefenders. 2018. To Them, We're Not Even Human: Marginalised Human Rights Defenders in Uganda, Kenya, and Tanzania. Accessed November 12, 2020. Kampala: DefendDefenders: p. 25. Available at: https://defenddefenders.org/wp-content/uploads/2018/12/FINAL-REPORT_pdf-3-1.pdf.

12 DefendDefenders. 2018. To Them, We're Not Even Human: Marginalised Human Rights Defenders in Uganda, Kenya, and Tanzania. Accessed November 11, 2020. Kampala: DefendDefenders: p.26. Available at: https://defenddefenders.org/wp-content/uploads/2018/12/FINAL-REPORT_pdf-3-1.pdf.

13 Interview with William Amanzuru, held in Kampala, October 25, 2020.

14 Interview with William Amanzuru, held in Kampala, October 25, 2020.

15 Women Taking the Lead: Defending Human Rights and the Environment. March 2020. Belfast, Northern Ireland: Trócaire: p.1. Available at: https://www.trocaire.org/sites/default/files/resources/policy/women taking the lead lowres 1 0.pdf. 16 Interview held in Kampala on October 12, 2020. Interviewee requested anonymity for safety reasons.

17 Friends of Zoka. 2020. 'About Us' section of website. Accessed in Kampala on December 30, 2020. Available at: https://www.friendsofzoka.org/. 
18 Witness Radio. 2020. Land in Mubende: Guns, money and power grabbed over 1,975,834 hectares of land; broke families. Accessed in Kampala on November 20, 2020 at 6pm. Kampala: Witness Radio: p.2. Available at: https://witnessradio.org/download/reports/Land-Grabbing-In-Mubende-Report.pdf.

19 Ibid.

20 Witness Radio. 2020: 16.

21 lbid.

22 Ibid.

23 See, United Nations Basic Principles and Guidelines on Development-Based Evictions and Displacement, available at https://www.ohchr.org/Documents/Issues/Housing/Guidelines en.pdf.

24 Interview with Eron Kiiza, held in Kampala, October 11, 2020.

25 Ibid.

26 Ibid.

27 Interview with local leaders, held in Mubende district, October 13, 2020. Interviewee requested anonymity for safety reasons.

28 Ibid.

29 Interview with K. P. Eswar, Corporate Affairs Director for the Madhavani Group, held in Kampala, October 19, 2020.

30 Interview with Gilbert Oulanyah, held in Gulu district, November 12, 2020.

31 Interview with K. P. Eswar, Corporate Affairs Director for the Madhavani Group, held in Kampala, October 19, 2020.

32 Interview with Ochaka Lokrom, held in Gulu district, November 12, 2020.

33 For details, see Mutambukah 2020.

34 Interview with community member in Kween district. Interviewee preferred anonymity for safety reasons, held on October 13, 2020.

35 See "Benet Residents Battle Disability Meted by UWA," The Independent, October 26, 2020. Available at: https://www.independent.co.ug/benet-residents-battle-disability-meted-by-uwa/.

36 Letter from the International Network for Economic, Social and Cultural Rights, addressing Uhuru Kenyatta, President of Kenya. The letter was submitted on July 9, 2020.

37 Interview with Ole Naiput, held in Kampala via WhatsApp, November 30, 2020.

38 Ibid.

39 Ibid.

40 Interview held in Kampala via Whatssap with Jackson Shaa, Executive Director of Narasha Community Development Group, November 18, 2020.

41 United Nations. Kenya / Embobut Forest: UN rights expert calls for the protection of indigenous people facing eviction. Available at: https://www.ohchr.org/EN/NewsEvents/Pages/DisplayNews.aspx?NewsID=14163\&LangID=E. 42 Photo obtained from https://www.downtoearth.org.in/blog/climate-change/this-indigenous-tribe-of-kenya-needsthe-world-s-attention-61577. 
43 Kiptum, Yator. 2018. "This Indigenous Tribe of Kenya Needs the World's Attention." September 10, 2018. DownToEarth. Accessed November 21, 2020. Available at: https://www.downtoearth.org.in/blog/climate-change/thisindigenous-tribe-of-kenya-needs-the-world-s-attention-61577.

44 Kiptum 2018.

45 Kiptum 2018.

46 Constitution of Kenya, 2010. Accessed from Kampala on January 25, 2021. Available at: http://extwprlegs1.fao.org/docs/pdf/ken127322.pdf.

47 Interview with Kiptum, held in Kampala via WhatssApp, November 18, 2020.

48 Save Lamu. 2019. Accessed on January 25, 2021. Available at: http://www.savelamu.org/about/savelamu/.

49 Ibid.

50 Human Rights Watch. 2018. 'They Just Want to Silence Us' Abuses Against Environmental Activists at Kenya's Coast Region.' Accessed on January 25, 2021. Available at: https://www.hrw.org/report/2018/12/17/they-just-want-silenceus/abuses-against-environmental-activists-kenyas-coast.

51 Ibid.

52 lbid.

53 Ibid.

54 Cultural Survival. 2015. Observations on the State of Indigenous Human Rights in the United Republic of Tanzania in Light of the UN Declaration on the Rights of Indigenous Peoples. Prepared for United Nations Human Rights Council, 2nd cycle of Universal Periodic Review of Tanzania. Cambridge, MA: Cultural Survival.

55 Cultural Survival 2015: 2.

56 Telephone interview, held in Kampala via Signal on November 19, 2020. Interviewee requested anonymity for safety reasons.

57 Erin Kempster. 2014. Brief: Gender and Land Rights Debate in Tanzania. Accessed on January 25, 2021 from Kampala. Available atL http://www.focusonland.com/fola/en/countries/brief-gender-and-land-rights-debate-intanzania/.

58 Kempster, Erin. 2019. Brief: Gender and Land Rights Debate in Tanzania. Focus on Land in Africa. Accessed on November 20, 2020, p.1. Available at: http://www.focusonland.com/fola/en/countries/brief-gender-and-land-rightsdebate-in-tanzania/.

59 lbid.

60 Email interview with LERD from Tanzania, conducted November 2020. Interviewee requested anonymity for safety reasons.

61 lbid.

62 Ibid.

63 Email interview with another LERD from Tanzania, conducted November 2020. Interviewee requested anonymity for safety reasons.

64 DefendDefenders 2018: 24.

65 DefendDefenders 2018: 26.

66 DefendDefenders 2018: 26.

67 Interview with a LERD in Tanzania. 
68 DefendDefenders 2018: 26.

69 DefendDefenders 2018: 27.

70 DefendDefenders 2018.

71 Civicus. 2019. TANZANIA: Despite threats, we will not retreat from defending the rights of our communities. Accessed from Kampala on January 25, 2021. Available at: https://www.civicus.org/index.php/mediaresources/news/interviews/3712-tanzania-despite-threats-we-will-not-retreat-from-defending-the-rights-of-ourcommunities.

72 Ibid.

73 Ibid.

74 Email interview with Sam Nangaria, a LERD from Tanzania, conducted November 12, 2020.

75 Email interview with Susana Nordlund from Kampala, conducted November 12, 2020.

76 Ibid.

77 lbid.

78 Email interview with Regina Asinde in Kampala, conducted November 9, 2020.

79 lbid.

80 For details of this incident, see Kakaire, Sulaiman, "Why Police Raided NGOs, Froze Shs 7bn," Observer, October 23, 2017. Available at: https://observer.ug/news/headlines/55568-why-police-raided-ngos-froze-shs-7bn.html .

81 Face to face interview with William Amanzuru in Kampala, conducted November 2020.

82 Email Interview with Regina Asinde, conducted from Kampala, November 2020.

83 Interview with Sam Mucunguzi, conducted from Kampala, November 2020.

84 Email Interview with Regina Asinde, conducted from Kampala, November 2020.

85 lbid.

86 Email interview with Susanna Nordlund, conducted from Kampala, November 12, 2020.

87 Interview with Regina Asinde.

88 Interview with Regina Asinde.

89 Hill, Christina. 2018. "Fighting Back: A Global Protection Strategy for EarthRights Defenders." EarthRights International, Washington, DC, 7. Available at: https://earthrights.org/wp-

content/uploads/11_28_18_ERD_Report_V3_Letter-compressed.pdf.

90 Hill 2018: p.7.

91 "The Ogiek Peoples' Development Program: Fighting for Rights to Identity" (website). Available at: https://globalfundcommunityfoundations.org/news/the-ogiek-peoples-development-program-fighting-for-rights-toidentity/.

92 For details, visit Kenya Community Development Foundation website, "Who We Are." Available at: http://www.kcdf.or.ke/index.php/about-us/who-we-are.

93 DefendDefenders website. Accessed October 2020. Available at: https://defenddefenders.org/about-us/about-us/. 94 DefendDefenders website. Accessed October 2020. Available at: https://defenddefenders.org/about-us/about-us/. 95 DefendDefenders website. Accessed October 25, 2020. Available at: https://defenddefenders.org/about-us/about$\underline{\mathrm{uS} / .}$

96 Global Witness 2020. 
97 Global Witness 2020.

98 These recommendations are largely drawn from Global Witness 2020. 